\title{
Policy uncertainty, derivatives use, and firm-level FDI
}

\author{
Quang Nguyen ${ }^{1}$, Trang Kim² \\ and Marina Papanastassiou ${ }^{1}$
}

${ }^{1}$ Business School, Middlesex University, London NW4 4BT, UK; ${ }^{2}$ Faculty of Banking and Finance, Foreign Trade University, 91 Chua Lang ST., Dong Da Dist, Hanoi, Vietnam

\section{Correspondence:}

Q Nguyen, Business School, Middlesex University, London NW4 4BT, UK.

Tel: +(44)07475081518;

Fax: (+44)(0)20 84116607 ;

e-mail: Q.Nguyen@mdx.ac.uk
Received: 12 March 2016

Revised: 3 March 2017

Accepted: 14 March 2017

Online publication date: 31 July 2017

\begin{abstract}
We explore the link between uncertainty in economic policy, firm-level FDI, and firm hedging behavior - building upon a newspaper-based index of economic policy uncertainty (EPU). We find that the relative difference in EPU between home and host country has a significant relationship with FDI. Firms increase their FDI level in countries, which have a low level of EPU relative to their home country. In addition, firms use derivatives more intensively in response to an increase in EPU. Interestingly, the link between EPU and corporate derivatives use varies according to the type of firm. Domestic MNCs make the most effective use of derivatives to hedge against EPU exposure.
\end{abstract}

Journal of International Business Studies (2018) 49, 96-126.

https://doi.org/ | 0.1057/s4 I 267-0 17-0090-z

Keywords: firm FDI; hedging behavior; derivatives use; economic policy uncertainty; risk exposure

The online version of this article is available Open Access

\section{INTRODUCTION}

Derivatives use has always been a matter of great interest among academics and policymakers. ${ }^{1}$ By definition, derivatives are instruments aiming to protect participants in financial markets from adverse movements in prices of the underlying assets. In this study, we explore a positive aspect of derivatives by viewing them as a firm management tool to address risk and uncertainty (Bartram, Brown, \& Conrad, 2011). Existing studies use various proxies to measure the level of uncertainty firms are exposed to. This includes stock return volatility, the dispersion in analyst forecasts, and input and output prices, as well as certain types of macroeconomic policy, including fiscal, monetary, and social security policies. Other studies use the country's risk level (Asiri, 2014; Kim, Papanastassiou, \& Nguyen, 2016) or change in political regimes (Durnev, 2010). These studies have provided important insights into risk and uncertainty factors driving firm behavior. In this study, we focus on Economic Policy Uncertainty, an important but unexplored source of uncertainty relating to economic policy. ${ }^{2}$ Hereafter we use the acronym EPU to refer to this uncertainty. We explore whether EPU plays a consistent and significant role in explaining firm-level FDI and corporate derivative. 
Before moving on, we would like to clarify exactly what EPU refers to in this study. In line with Baker, Bloom, and Davis (2016) and Davis (2016), we focus on uncertainty regarding who makes economic policy decisions, what economic policy actions will be undertaken and when, and the economic effects of policy actions (or inaction). We explore both near-term aspects (e.g., when the government adjusts its policy rate) and longer-term aspects (e.g., how to implement entitlement programs). In doing so, our study contributes to the emerging literature initiated by the influential work of Bloom (2009). This strand of literature focuses on the role of policy uncertainty in determining firm behavior. Firms are often exposed to a significant amount of uncertainty about the timing and content of government policy changes. The uncertainty of future policy decisions can significantly increase the uncertainty related to firms' activities and influence firms' perception of risk. On the other hand, because derivatives are an important instrument for firms to address risk exposure, it is of interest to explore the link between EPU, derivatives use, and firm-level FDI.

To better understand the motivation behind our approach, we consider an August 12, 2015 news report from the widely circulated English-language newspaper, China Daily: "PBOC signals important change in managing the exchange rate." This story highlighted the unanticipated move by the People's Bank of China (PBOC) to depreciate its daily fixing for the Chinese Yuan against the US dollar. This news conveys uncertainty in China's exchange rate policy, not only in terms of the timing of its implementation, but also its impact on the economy once implemented. We wonder how this uncertainty is correlated with the firm performance. In relation, because derivatives are a firm's risk management instrument, it makes sense to explore whether firms use derivatives more intensively in response to policy uncertainty. ${ }^{3}$

Our study relates to a newspaper-based index of economic policy uncertainty (EPU) that builds upon a novel method by Baker et al. (2016). Relative to other text sources and types of data, the newspaper-based EPU indices contain useful information about the extent and nature of economic policy uncertainty. Also, these indices can be extended to many countries and can look back in time. In the context of our study, the EPU index enables us to objectively observe the amount of uncertainty leading up to, and following, the passage of economic policies for a cross-section of eight countries in our sample. It allows for a continuous tracking of policy uncertainty compared with the alternatives, such as elections. It is also worth noting that instead of focusing on particular types of policy - such as monetary policy - we focus on the overall level of EPU in the economy, and hence its aggregate effect on firm behavior.

We contribute to the literature by linking national policy uncertainty to firms' real managerial decision-making - in this case FDI and corporate derivatives use. Our study quantifies the effect of EPU on firm level FDI and hedging behavior. An interesting feature of this study is that it explores policy uncertainty in various countries across time. We focus the analysis on a sample of 881 nonfinancial firms from eight East Asian countries from 2003 to 2013. We chose this sample for the following reasons. First, although literature on derivatives use has blossomed, most empirical studies focus on non-financial, American firms; research on hedging behavior among East Asian firms remains relatively scarce, even though they have become the world's key derivatives users. ${ }^{4}$ Second, our sampled firms are located in countries with different economic and financial development levels, from the world's third and second largest economies (Japan and China), to newly industrialized countries (Singapore and Hong Kong), and then emerging markets (Thailand, the Philippines, Indonesia, and Malaysia). Additionally, these sample countries are also heterogeneous in terms of economic, political, and business environments. Country heterogeneity allows us to focus on differences in economic policy uncertainty that is arguably exogenous to firm derivative use. Lastly, given that our sample mainly consists of domestic firms - nearly $45 \%$ - we would expect the role of EPU to become more salient in driving firm behavior.

Our study also contributes to international business literature in two aspects. First, we highlight the role of EPU in deriving firm's FDI. Specifically, we show that difference in EPU between home and host country has a significant relationship with level of FDI flow from home-based firms to host country. Second, we examine whether the level of exposure to EPU - which we define as the percentage change in the rate of return on a firm's common stock against a $1 \%$ change in the EPU index - is conditional on the type of firm. Most existing studies on exposure focus exclusively on multinational corporations (hereafter MNCs) 
simply because MNCs engage more in overseas operation and trade (see Bartov and Bodnar, 1994; Faff and Marshall, 2005). Yet a purely domestic firm is exposed to EPU in the home country to a large extent. Whether MNCs are more exposed than domestic firms is not well understood. In relation, although the benefits of hedging from reducing exposure are well established, little is known about whether derivative activities of MNCs are associated with a greater reduction in exposure than other firms. In this study, we explore the link between derivatives use and exposure to EPU by comparing three types of firms: domestic firms, MNCs, and foreign affiliates. Further, our study covers the 2003-2013 period, which provides a natural experiment to investigate the dynamic relationship between EPU exposure and derivatives use when firms faced exogenous shocks caused by the global financial crisis of 2007-2008.

Our main findings can be summarized as follows. We find a positive relationship between the ratio of EPU at home country to EPU at host country and FDI. In addition, EPU is negatively associated with firm performance. It also increases the use of derivatives, after controlling for firm-specific factors. This effect is distinct from general economic risk and uncertainty in each country, as well as global economic uncertainty. We also provide an interesting finding - the use of financial derivatives by domestic firms and domestic MNCs significantly contributes to a reduction in exposure to domestic country EPU. Interestingly, compared to domestic firms and foreign affiliates, derivatives use by MNCs is more effective in reducing EPU exposure.

\section{SOME BACKGROUND INFORMATION}

While firms in East Asian countries have been playing an important role as active participants in derivatives markets, the reasons why East Asian non-financial firms hedge are not well explored. Likewise, the fundamental questions whether the use of derivatives increases firm value and/or reduces exposures that firms face are still unknown. While firms in the US and Europe have quite similar economic, financial, and social environments, our sample of East Asian countries has a great heterogeneity in economic and institutional environments. Regarding risk exposure, Pan, Fok, and Liu (2007) show that exposure to foreign exchange risk by Asia-Pacific firms appears to be much more widespread than is typical for the large, Western industrialized economies. Further, the extent of their exchange rate exposure has not diminished over the last decade. Kho and Stulz (2000) studied the currency exposure of the banking sector in five East Asian countries during the Asian financial crisis. They found that currency depreciations had a negative impact on the sector's stock returns only in Indonesia and the Philippines. Relatedly, Muller and Verschoor (2007) find that the number of firms that are significantly exposed to US dollar exchange risk contemporaneously varies from $20.5 \%$ in Singapore to $30 \%$ in Thailand, while the number of firms exposed to Japanese yen exchange risk varies from $20 \%$ in Hong Kong to $27 \%$ in Indonesia.

The literature on the link between derivatives and risk exposure among East Asian firms is still few. Parsley and Popper (2006) find that firms in East Asia were less hedged under pegged exchange rates. Allayannis, Brown, \& Klapper (2003) study the exchange rate hedging practices in eight East Asian countries between 1996 and 1998 by exploring the relative performance of hedgers during and after the crisis. They note that using derivatives does not reduce foreign exchange exposure by East Asian firms - those that used derivatives before the crisis performed just as poorly as non-users during the crisis. During post-crisis, derivatives use somewhat improved firm performance, but this result appears to be explained by an exchange rate risk premium.

\section{RELATED LITERATURE AND HYPOTHESIS DEVELOPMENT}

\section{Related Literature}

Our study directly relates to literature on the effect of government policy on firm behavior. Governments shape the environment in which firms operate by setting the rules of the game through policy formation and regulations. ${ }^{5}$ They levy taxes, provide subsidies, enforce laws, regulate competition, and define environmental policies, among other things. Government economic policy often has significant impacts, which are largely nondiversifiable. Thus, firms make real economic decisions based on expectations about the future economic policy environment, which is naturally uncertain. Pástor and Veronesi (2012) make a distinction between two types of uncertainty: policy uncertainty and political uncertainty. Policy uncertainty relates to the uncertain impact of a given government policy on the profitability of the private sector. Political uncertainty, on the other 
hand, is broadly defined as uncertainty about the government's future actions.

To proxy for political uncertainty, Julio and Yook (2012) and Durnev (2010) use election years. Julio $\&$ Yook (2012) find that corporate investment falls around national elections, while Durnev (2010) finds that corporate investment is $40 \%$ less sensitive to stock prices in election years. Huang, $\mathrm{Wu}$, Yu, and Zhang (2015) use crisis events as a proxy for political risk to explore their effect on corporate payout policy. They find that political risk makes existing dividend payers more likely to terminate dividends and non-payers less likely to initiate dividends. In relation to these studies - and in the spirit of the Baker, Bloom, and Davis (2016) index the index of economic policy uncertainty developed in this study complements and adds value to them. For instance, election years do not capture the heterogeneity in policy uncertainty that may occur between elections. Intuitively, such heterogeneity is likely significant given the infrequency of elections and the many uncertainty-inducing events that happen in non-election years, such as debate over the stimulus package, the debt ceiling dispute, wars, and financial crashes. ${ }^{6}$

Studies on the relationship between policy uncertainty and investment find a negative correlation, i.e., an increase in uncertainty predicts a reduction in investment. There are various reasons for a depressing effect of uncertainty on investment. Bernanke (1983) shows that firms delay investment in the face of uncertainty associated with changes in the country's monetary, fiscal, or macroeconomic policies. Bloom, Bond, and Van Reenen (2007) show that a change in the regulatory environment increases real option values, making firms more cautious when investing or disinvesting. On the other hand, Julio and Yook (2012) argue that declined investment expenditures might occur during times of political uncertainty around national elections.

Baker et al. (2016) provide further insights into this interesting strand of literature by proposing a newspaper-based index of EPU to objectively measure policy uncertainty. ${ }^{7}$ Given the increasing trend of policy changes observed in the US, it is expected that policy uncertainty may become more important over time. Using the Baker et al. (2016) index, Gulen and Ion (2015) find a strong negative relationship between firm-level capital investment and the aggregate level of policy uncertainty. Finally, using a variation of the Baker et al. (2016) measure and extending it to an international setting, Brogaard and Detzel (2015) find that when economic policy uncertainty increases by $1 \%$, market returns fall by $2.9 \%$ and stock market volatility rises by $18 \%$.

\section{Literature on Firm Specifics and Derivative Use}

There have been a great number of studies on firmlevel determinants of the use of derivatives. Due to space constraint, we focus on the most relevant studies. Modigiliani and Miller's (1958) seminal paper shows that the efficient market financing policy of firms is irrelevant - hedging does not affect firm value. Hence, the incentives of hedging are built on market imperfections and on situations that hedging can increase the expected cash flows of firms. Existing evidence, however, provides mixed support for the theories of hedging. Judge (2006) finds a robust relationship between financial distress costs and foreign currency hedging decisions, which is much stronger than in many previous studies in the UK. Recently, Chen and King (2014) examined 1832 non-financial American firms and present significant evidence that is consistent with financial distress cost arguments. In contrast, Charumathi and Kota (2012) state that no evidence exists to support this hypothesis. Supanvanij and Strauss (2010) find that tax loss carry-forwards are an important factor in determining the use of foreign currency derivatives, while Kumar and Rabinovitch (2013) indicate that firms use derivatives to increase the present value of tax losses. In contrast, Gay, Lin, and Smith (2011) do not find any evidence in support of the tax incentive to increase debt capacity. Finally, in a series of studies in the gold mining industry Tufano (2003) notes that hedging is an important risk management instrument; yet Brown, Crabb, and Haushalter (2006) find that selective hedging is rarely successful among firms who are unlikely to have an informational advantage.

Empirical studies on testing the agency cost of debt theory also provide inconclusive evidence. Chen and King (2014) find evidence to support agency costs of debt theory. Yet Charumathi and Kota (2012) do not find evidence in support of the agency cost of debt hypothesis. This finding is consistent with a recent study by Lievenbrück and Schmid (2014), and earlier studies such as Nance, Smith, and Smithson (1993). ${ }^{8}$

\section{Hypothesis Development}

\section{Linking EPU and FDI}

Economic policies have important implications for taxation, spending, monetary and trade policy, and industry regulation. Uncertainty in policy may 
influence firm fundamentals, such as investment opportunities, cash flows, or risk-adjusted discount factors. Baker et al. (2016), along with Gulen and Ion (2015), report that a rise in economic policy uncertainty signals a significant decrease in corporate investment. Regarding FDI, Beazer and Blake (2011) argue that firms compare uncertainty across possible investment locations, choosing the less risky option. The default investment location, which represents the baseline level of uncertainty, is the firm's home country. For example, Tallman (1988) and Grosse and Trevino (1996) explore the effect of home country political risk on firm's decision to invest in the US. They find that firms from countries with a higher degree of internal political, economic, or social instability show greater FDI into the US. In doing so firms reduce exposure to home country risks. Likewise, Lee and Song (2012) find significant production shifts among foreign subsidiaries of multinational corporations (MNCs), due to macroeconomic uncertainty in their host countries.

Building upon existing literature, we propose that firms evaluate EPU abroad relative to the level of EPU they experience at home. Firms are more willing to invest in countries with a lower level of EPU than their home country.

Hypothesis 1: A positive relationship exists between FDI and the ratio of EPU at home country to EPU at host country.

\section{EPU and derivatives use}

Given the importance of policy uncertainty in firm performance, it is interesting to explore how firms respond to EPU. In relation to extant literature, there are two important and related questions. The first question is how EPU differs from other fundamental risks. The literature on EPU has shown it to be an economically important risk factor, which differs from other conventional and fundamental risks. Pástor and Veronesi $(2012,2013)$ model firms with differing exposure to policy uncertainty. They note that policy risk premium differs from the more traditional economic risk premia, which are driven by fundamental shocks. The policy risk premium compensates firms for political uncertainty, which makes investors uncertain about which policy the government might adopt in the future. In addition, the risk premium induced by impact shocks represents compensation for a different aspect of uncertainty about government policy - uncertainty about the impact of the prevailing policy on profitability.
Importantly, Pástor and Veronesi $(2012,2013)$ posit that firms with greater exposure to policy uncertainty typically have higher expected returns, although the phenomenon is state dependent and can potentially have the opposite effect. Likewise, innovations in policy uncertainty adversely affect investment opportunities and firm performance by increasing uncertainty.

In relation, Brogaard and Detzel (2015) note that government taxation, expenditure, monetary, and regulatory economic policies can have market-wide economic effects, which are largely non-diversifiable. Firms make real economic decisions based on expectations about the future economic policy environment. As such, even market-benevolent policymakers can increase risk by generating an environment of uncertainty about their future economic policy decisions. Brogaard and Detzel (2015) also find that innovations in economic policy uncertainty command a significant negative risk premium in the cross-section of stock returns, even when controlling for innovations in other uncertainty measures in addition to market, size, value, and momentum factors. Overall, there is a negative contemporaneous correlation between changes in EPU and market returns - as such the Brogaard and Detzel (2015) study presents evidence suggesting that EPU is an economically important risk factor.

The second question is why EPU causes firms to hedge more. To explore this question, we incorporate EPU exposure - which we define as the percentage change in the rate of return on a firm's common stock against a $1 \%$ change in the EPU index. Our approach is in line with the literature on firm exposure to risk and uncertainty (e.g., Hutson, \& Stevenson, 2010; Allayannis, \& Weston, 2001). Extant literature (e.g., Allayannis, \& Weston, 2001) finds that derivatives are an effective instrument to hedge against exchange and interest rates. Likewise, we develop the analysis based on the reasoning that if derivatives prove to help firms reduce exposure to EPU, firms will have incentive to use derivatives more intensively.

Bartram et al. (2009) highlight that firms located in countries with greater economic, financial, and political risks are more likely to use derivatives. On the other hand, firms based in less risky countries may have lower expected financial distress costs and less incentive for risk management. Recently, Azad, Fang, and Hung (2012) and Kim, Papanastassiou and Nguyen (2016) found evidence that higher degrees of economic, financial, and political risk encourage firms to use derivatives more intensively. 
Because firms have been using financial derivatives as important risk management instruments to hedge exposure to market risks, we would expect that these instruments enable firms to hedge policy-related uncertainty. ${ }^{9}$ Using a propensity score matching (PSC) approach, Bartram et al. (2011) note that overall, non-financial firms are motivated to use derivatives for risk reduction. Huang et al. (2015) suggest that uncertainty in government policies may significantly increase how managers perceive a firm's cash flow risk, largely because the cash flows of individual firms are exposed to both idiosyncratic and aggregate shocks. Beber, Brandt, and Kavajecz (2009) observe that higher macroeconomic uncertainty leads to a greater increase in derivatives trading volume, after macroeconomic news and firms unwind those derivatives positions shortly after that. This finding implies that firms use options to hedge or speculate on macroeconomic news.

Hypothesis 2: A positive relationship exists between EPU and derivatives use; firms use derivatives more intensively to reduce exposure to EPU.

Hypothesis 2 suggests that firms use derivatives more intensively in response to EPU. Naturally, we wonder whether this response brings any benefit to firms. We explore two potential benefits of using derivatives related to firm performance and reducing exposure to EPU. Specifically, we examine the role of derivatives in moderating the effect of EPU on firm performance and explore how derivatives enable a firm to respond efficiently to policy uncertainty. Because derivatives are risk management instruments, we expect that a firm can reduce EPU exposure and the impact of policy uncertainty on its performance using derivatives more intensively. Our conjecture is built upon a number of theoretical and empirical studies. In one theoretical study, Bolton and Oehmke (2015) extend the standard incomplete contracts framework in corporate finance, by introducing derivative contracts that allow firms to arrange state-contingent transfers with separate derivative counterparties. Specifically, derivatives allow for payments tied to publicly observable and verifiable events that are correlated with firms' unobservable (or unverifiable) cash flow outcomes. Derivatives are supplied by derivative counterparties that are subject to moral hazard, which is mitigated via collateral requirements, as observed in Biais et al. (2015).
Within this framework, Bolton and Oehmke (2015) show that by allowing transfers of cash from world states correlated with high-cash flow realizations to states correlated with low-cash flow realizations, derivative contracts help firms manage uncertainty more effectively.

As for empirical studies, Bartram et al. (2011) find that relative to firms that do not use derivatives, derivative users have lower cash flow volatility, idiosyncratic volatility, and systematic risk. Campello, Lin, Ma, and Zou (2011) show that derivative use relaxes firm financing by reducing the likelihood of states in which the costs of financial distress are high and firms engage in risk-shifting. Likewise, Chang, Hsin, and Shiah-Hou (2013) describe the use of foreign currency derivatives as 'real actions,' since they directly mitigate the impact of currency risk on the real cash flows of firms. Zhou and Wang (2013) note that numerous multinational companies nowadays resort to financial derivatives to reduce the adverse effect of foreign exchange exposure in their value enhancement activities. In sum, we propose that derivatives enable firms to reduce exposure to EPU; hence, they reduce the negative effect of EPU on firm performance.

Hypothesis 3A: There is a negative relationship between corporate derivatives use and exposure to EPU.

Hypothesis 3B: More intensive use of derivatives reduces the effect of EPU on firm performance, as measured by Tobin's Q.

\section{Derivatives use and exposure by firm type}

Hypothesis 3A proposes that there is a negative relationship between derivatives use and exposure to EPU. An interesting question is whether this relationship is conditional on firm type. We use the Corporate Affiliates database to classify firm types. We distinguish between two types of domestic firms, i.e., between uninational domestic firms firms with no overseas investments - and domestic MNCs - firms that are part of a domestically owned MNC. Similarly, foreign affiliates are the incoming MNCs with a parent company based elsewhere in the world (Pantzalis, Simkins, \& Laux, 2001; Castellani, \& Zanfei, 2006).

We propose that a variation exists in the effect of derivatives use, due to differences in firm-specific resources and capabilities. In particular, such 
variation can be linked to firm-specific advantages (FSAs) of MNCs and the distinctiveness of other firms. Building upon internationalization theory (Buckley, \& Casson, 1976; Dunning, 1977), international business scholars have found that MNCs should be able to exploit cost differentials on a global scale due to operation across borders (Allen \& Pantzalis, 1996; Chung, Lee, Beamish, \& Isobe, 2010). MNCs, by virtue of their global scope and strategy and their ability to span both internal and external business networks across national boundaries (Scott-Kennel \& Giroud, 2015), can have advantages in hedging exposure to a specific market or country EPU. Likewise, the literature highlights the advantages of MNCs in accessing international capital markets and the ability to exploit market imperfections through internal capital markets or networks of international subsidiaries (Park, Suh, \& Yeung, 2013). These advantages enable MNCs to better manage uncertainty related to home/host countries' regulations. In other words, FSAs enable MNCs to achieve superior performance in hedging against EPU.

In comparison to domestic firms, Dunning and Lundan (2008) note that MNCs have more opportunities than domestic firms to utilize a combination of organizational and external resources to spread market risks and enhance performance, by means of multinationality. Extant studies (e.g., Hughes, Logue, \& Sweeney, 1975; Fatemi, 1984; Michel and Shaked, 1986) show evidence that internationalization enables MNCs to have lower systematic risk, idiosyncratic risk, and total risk than domestic firms. Along this line, Allayannis and Ofek (2001) and Choi and Jiang (2009) find that MNCs may possess a superior capability to reduce exposure to market risks by means of derivatives. Dunning and Rugman (1985) further indicate that MNCs have a greater degree of freedom than domestic firms. For example, while domestic firms have to rely on limited financial instruments to hedge their exposure, MNCs have opportunities to engage in additional hedging tools (Pantzalis et al., 2001).

The literature also emphasizes the importance of country-specific advantages (CSAs) - including economies of scale and access to natural resources in the operation of domestic MNCs - and shows that MNCs are better at exploiting CSAs than their domestic counterparts (Bhaumik, Driffied, \& Zhou, 2016). Likewise, Choi and Jiang (2009) find that MNCs face smaller and less significant exchange rate exposure than non-MNCs. These advantages increase the competitive edge of MNCs over domestic firms and enable MNCs to use derivatives to reduce exposure to country and market risks better than domestic firms.

Next, we explore the comparison between MNCs and foreign affiliates. Recent IB and international finance studies suggest that foreign affiliates tend to be at a disadvantage as they often suffer from liability of foreignness (Blass \& Yafeh, 2001; Bell et al., 2012). Foreign affiliates usually lack knowledge about local cultures and networks connecting them with important actors in host country's economy. They also have a weak link to local institutional setting (Zaheer, 2002; Bell et al., 2012). Thus, we would expect that foreign affiliates face more difficulties in implementing derivatives activities than domestic MNCs. These difficulties reduce the effectiveness of derivatives in reducing EPU exposure.

In sum, building upon extant literature, we propose the following hypothesis:

Hypothesis 4: Derivatives use by domestic MNCs is associated with a greater reduction in EPU exposure than it is among domestic firms and foreign affiliates.

\section{RESEARCH DESIGN}

\section{The Policy Uncertainty Index}

A key feature of this study is its exploration of the link between policy uncertainty and firm hedging behavior. As mentioned, developing an objective measure for policy uncertainty is complicated. Following Baker et al. (2016), we explore coverage of policy-related economic uncertainty in leading newspapers as an indicator for the intensity of concerns about economic policy uncertainty. ${ }^{10}$ The reasoning behind this approach is that when certain kinds of uncertainty matter, they are likely to be reported by journalists through the use of certain words. More specifically, it is assumed that the media is able to gauge any uncertainty indicated by market outcomes, professional economists, and political debate, and to draw the general public's attention to this uncertainty through the recurrent use of specific words.

To harvest news articles, we use Access World News, which contains articles from leading national papers and news sources from around the world. We include articles in the policy uncertainty index if they state, imply, or suggest any of 
the following: an uncertainty about what economic policy will be adopted (with specific keywords); whether or when it will be adopted; or uncertainty about its economic effects. For the purpose of linking policy uncertainty and derivatives use, we parallel the Baker et al. (2016) approach by utilizing the number of newspaper articles containing three categories of terms related to each respective country: economy (E), policy $(\mathrm{P})$, and uncertainty $(\mathrm{U})$. We use the following keywords: (E) \{economic, economy\} (U): \{uncertainty, uncertain, risk $\}$ (P) \{policy, regulation, legislation, government $\}$. Our objective is to select articles that discuss uncertainty about economic policies in our sample countries. The mere mention of a country's name in an article does not necessarily imply that its economic policy is uncertain. Hence, we discard articles that only mention a specific country, but are actually about uncertainty in another country. All news searches were undertaken in English, because Access World News translates articles from native languages to English. To help develop suitable E, P, and U term sets, we consulted persons with native-level fluency and economic expertise in the relevant language and country. ${ }^{11}$

To develop our EPU index, we consider the leading newspapers in each country of our sample - such as the South China Morning Post, China Daily, Asahi, Yumiuri, the Business Times, the Straits Times, The Standard, Daily Express, Malaysia Today, Pattaya Mail, and The Bali Times. Like Baker et al. (2016), we scale the raw counts by the total number of articles in these newspapers that satisfy our search criteria, in the same newspaper for each East Asian country in our sample. This process yields an EPU series for each country, which we normalize to unit standard deviation for the 2003-2013 time period. Finally, we rescale the EPU series to an average value of 100 from 2003 to 2013.

It is worth exploring the link between our constructed EPU index and some significant events happened in our sample countries. For instance, the incidence related to August 12, 2015 news mentioned in the introduction corresponds to a change of $11.25 \%$ increases in EPU. The political coup in Thailand in 2006 was reflected by a significant increase of $28.86 \%$ in EPU during that year. Likewise, election in the Philippines in 2010 is associated with a $25.22 \%$ increase in EPU in the Philippines during that period. These examples highlight the relevance of our EPU index in capturing uncertainty at national level.

\section{Measures of Corporate Use of Derivatives}

We collected the information about derivatives use from firms' annual reports. Until now, information about the notional principal amount of derivative instruments is considered an off-balance sheet item; therefore, there is no database containing data about derivatives use of non-financial firms in East Asian countries. Hence, we hand-collected these data directly from annual reports. We verified data accuracy by searching a subset of firms' annual reports. The electronic annual reports in PDF format were obtained via websites of each firm, or from Morningstar, an independent investment research company that links directly to each company's recent annual report, or from the stock exchanges of each country. Because the eight countries in our sample have different local currencies with different values, it may result in sampling bias. Hence, we used the common currency for the amount of derivatives use; for all other financial data we used US dollars (USD). For annual reports in which reporting currency was not USD, we converted all hand-collected data into USD using exchange rates from the Datastream database. We augmented this database on derivatives use from annual reports, with financial data on explanatory variables from the Datastream database. For data not available on Datastream, we searched annual reports of firms to fill in as much missing data as possible.

Next, to measure how intensely a firm uses derivatives, we construct a continuous variable, which is defined as the total notional amount of derivative contracts scaled by the firm size for a user and zero for a non-user. We searched annual reports for information about the use of derivatives and classify firms as users if their annual reports specifically mentioned the use of any type of derivative contracts - forwards, swaps, futures, and options. Almost every firm stated that they did not enter into derivative contracts for trading or speculation purposes; we therefore assume that all firms in our sample use derivatives mainly for hedging.

We do not use accounting definitions because accounting standards differ across countries, and accounting classification does not always reveal a firm's intention for holding a derivative position. We focus on textual descriptions; as such, a firm is classified as a derivatives user if it has any numerical or narrative disclosure of derivatives use in a fiscal year. Applying this measure, we are able to 
investigate the use of derivatives for a large sample of firms over a long period of time.

\section{Sample Selection}

Like Kim, Papanastassiou and Nguyen (2016), we focus the analysis on 881 non-financial firms across various industries located in eight East Asian countries (Singapore, Hong Kong, the Philippines, Thailand, Malaysia, Indonesia, China, and Japan) from 2003 to $2013 .{ }^{12}$ Please refer to Appendix C for further discussion on our sample selection. Although we use the same sample of firms as Kim et al. (2017), the two studies differ in many ways. Kim et al. focus on the link between derivatives and institutional/national governance quality such as corruption, rules of law, and country risk. In this article, we explore the role of EPU in driving firm's FDI and hedging behavior. On the one hand, EPU is a more objective measure of uncertainty than institutional quality. On the other hand, we have spent a part of the article to show that the EPU contains uncertain aspects of macroeconomic environment - which have not been captured by institutional quality. The link between EPU and derivatives use is highly significant - even after controlling for institutional quality.

It is worth noting that our sample consists of 389 domestic firms, 427 domestic MNCs, and 65 foreign affiliates (Table 1). We use the Corporate Affiliates database to classify firm types. We distinguish between two types of domestic firms, i.e., between uninational domestic firms - firms with no overseas investments - and domestic MNCs - firms that are part of a domestically owned MNC. Similarly, foreign affiliates are the incoming MNCs with a parent company based elsewhere in the world (Pantzalis et al., 2001; Castellani \& Zanfei, 2006). Summary statistics on the use of derivatives by the sample firms is reported in Table 2. Across all countries, approximately $53.5 \%$ of our sample observations use at least one type of derivative, while the usage rate in Japan, the Philippines, and Thailand is $100 \%$, indicating that derivatives use is common among non-financial firms in East Asian countries. Firms using foreign currency derivatives account for $42.55 \%$.

\section{EMPIRICAL RESULTS AND ANALYSIS}

For ease of exposition, we first elaborate on the key variables in our analysis.

\section{Firm Specifics}

\section{Operational hedging}

Empirical research documents that many firms actively manage exposure to market risks through the use of operational hedging (Choi \& Jiang, 2009; Pantzalis et al., 2001; Berghöfer \& Lucey, 2014) - as in Pantzalis et al. (2001) - so it is necessary to control for operational hedging to understand firm exposure. We use the dummy variable GEOMARKT, which has a value of one for firms that have sales

Table 1 Definitions of variables

\begin{tabular}{|c|c|c|}
\hline Variables & Definitions & Sources \\
\hline$\left|\hat{\lambda}_{i j t}\right|$ & Absolute value of exposure to country EPU of firm $i$ located in country $j$ in yeart & $\begin{array}{l}\text { Authors' } \\
\text { estimation }\end{array}$ \\
\hline EPU & Economic policy uncertainty index & $\begin{array}{l}\text { Authors' } \\
\text { calculation }\end{array}$ \\
\hline \multicolumn{3}{|l|}{ Control variables } \\
\hline Firm size & Natural logarithm of market value of total assets scaled by producer price index (PPI) & Datastream \\
\hline Leverage & Total debt to total assets & Datastream \\
\hline FORSALES & Foreign sales to total sales & Datastream \\
\hline GEOMARKT & $\begin{array}{l}\text { Dummy variable which has a value of one for firms that have sales markets in foreign } \\
\text { countries and zero otherwise }\end{array}$ & $\begin{array}{l}\text { Authors' } \\
\text { construction }\end{array}$ \\
\hline Cross-listed & Dummy variable which has a value of one for cross-listed firms and zero otherwise & Authors' \\
\hline $\begin{array}{l}\text { Industrial } \\
\text { diversification }\end{array}$ & $\begin{array}{l}\text { Dummy variable which equals one for firms operating in more than one business } \\
\text { segment in the SIC industry classification and zero otherwise }\end{array}$ & construction \\
\hline GDP per capita & (Gross domestic products (GDP)/midyear population) & World Bank \\
\hline $\begin{array}{l}\text { Financial system } \\
\text { deposits to GDP }\end{array}$ & $\begin{array}{l}\text { The demand, time, saving deposits in deposit money banks, and other financial } \\
\text { institutions as a share of GDP }\end{array}$ & World Bank \\
\hline Rule of law & $\begin{array}{l}\text { Index measuring the confidence of agents in abiding by the rules of society, the quality of } \\
\text { contract enforcement, and property rights with }-2.5 \text { (weak) to } 2.5 \text { (strong) }\end{array}$ & World Bank \\
\hline
\end{tabular}

This table summarizes predictions and defines the firm-specific and country-specific variables 


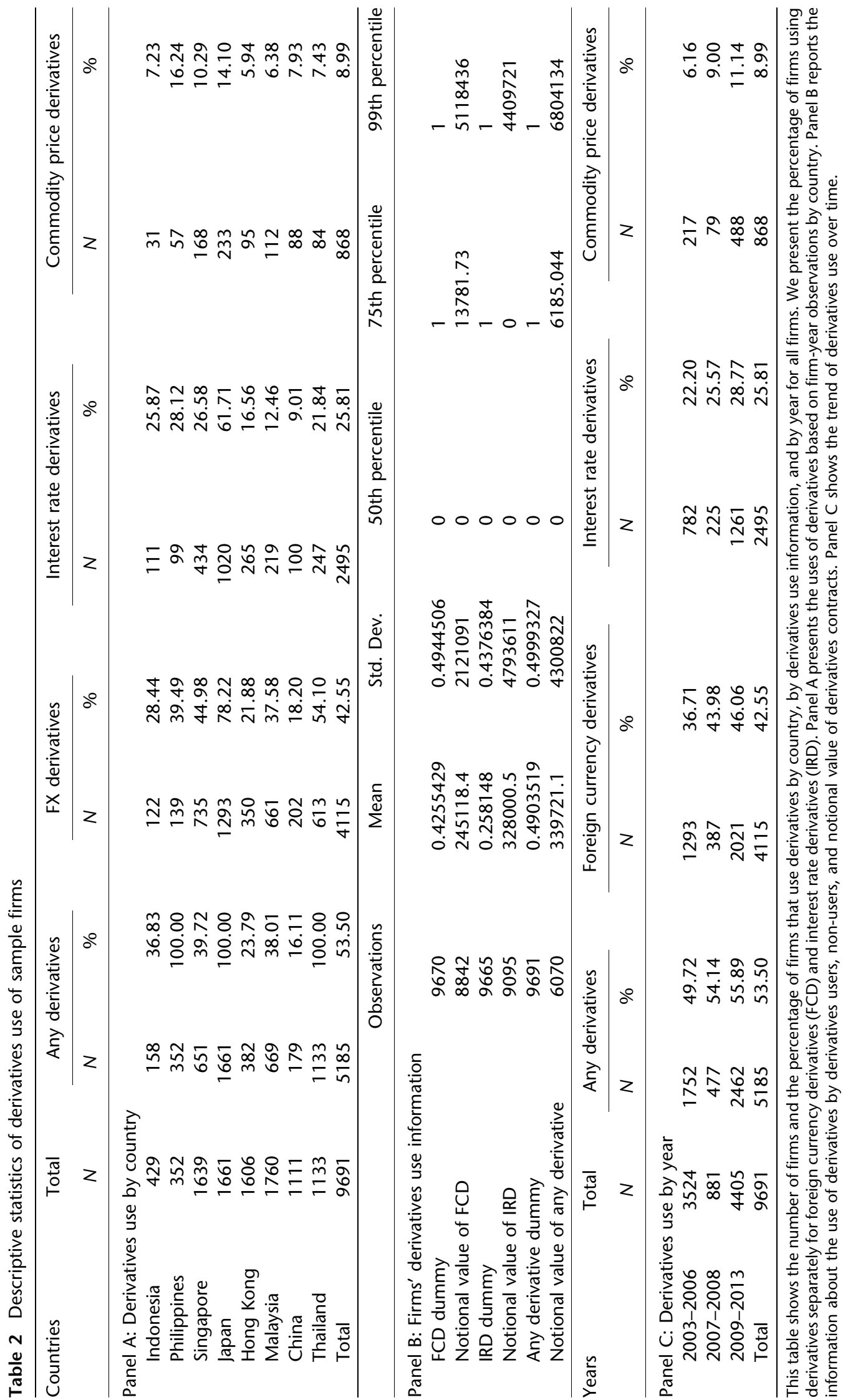


markets in foreign countries and zero otherwise. We use the diversification dummy, which equals one for firms operating in more than one business segment in the SIC industry classification and zero otherwise.

\section{International involvement}

It is well established in the existing literature that foreign sale ratios are important determinants of exposure (Jorion, 1990; Bodnar \& Wong, 2000; Allayannis \& Ofek, 2001), as they indicate that firms with a large proportion of foreign sales tend to be more exposed to market risks. Following Allayannis and Ofek (2001), we use the ratio of foreign sales to total sales, denoted as FORSALES, to measure a firm's degree of international involvement in this study.

\section{Firm size}

Recent studies have identified that smaller firms are more subject to market risk exposure than larger firms (Pantzalis et al., 2001; Hutson \& Stevenson, 2010), and MNCs are associated with smaller and less significant exchange rate exposure than nonMNCs (Choi \& Jiang, 2009). Thus, we use the natural logarithm of the book value of total assets as a proxy for firm size.

\section{Leverage}

The extent to which a firm is exposed to market risks has been shown to depend on leverage (He \& $\mathrm{Ng}, 1998$ ) as the use of derivatives reduces expected financial distress and bankruptcy costs (Smith \& Stulz, 1985; Froot, Scharfstein, \& Stein, 1993). We therefore use the ratio of total debts to total assets as our definition of leverage.

\section{Industrial diversification}

It is of interest to explore whether diversification reduces firm exposure to risk and uncertainty. We control for the effect of industrial diversification on firm value using the diversification dummy, which equals one for firms operating in more than one business segment in the SIC industry classification and zero otherwise.

\section{Country-level Control Variables}

We use GDP per capita to proxy for relative country performance, and financial system deposits to GDP to proxy for financial market development. We choose these two variables because an increase in GDP per capita and financial system deposits to GDP gestures growth in the economy and tends to signal a reduction in market risks. Additionally, Hutson and Stevenson (2010) find a significant negative link between exposure and the extent of creditor protection in a country. Thus, we use rule of law to proxy for country governance quality.

\section{Summary Statistics}

Table 3 presents summary statistics for both firmand country-specific variables described in the previous section for the sample firms. The means of exposure coefficients for EPU reported in the second column show that domestic firms have the highest overall exposure, while domestic MNCs have less exposure than domestic firms and foreign affiliates.

On the comparison between derivative users and non-users for domestic firms, panel A shows that derivative users have lower average exposure to EPU than non-users. This, however, is not statistically significant at any standard level. Yet we observe that derivative users have both significant lower average exposure to exchange rate and interest rate risks than non-users.

For domestic MNCs, the results indicate that derivatives users have lower overall exposure than non-users - as expected. All exposure of derivatives users is less relative to non-users and shows statistically significant differences in means at any standard level. Similarly, foreign affiliate derivatives users have lower exposure to EPU. A rather unexpected finding is that users have a higher exchange rate exposure than non-users. The mean difference, however, is not significant at standard levels.

\section{MULTIVARIATE ANALYSIS}

In this section, we will implement different model specifications to address our hypotheses. First, to test Hypothesis 1 we will explore the link between EPU and FDI. We then move on to investigate the determinants of derivative uses as elaborated in Hypothesis 2. Next, we explore the role of derivatives in reducing firm's exposure to EPU - by type of firms - as discussed in Hypotheses 3A, 3B, and 4.

\section{Linking EPU and FDI}

To explore the link between EPU and FDI, we combine the firms in our data with the fDi Markets database based on firm name. ${ }^{13}$ fDi Markets database is an online database maintained by fDi Intelligence - a specialist division of the Financial Times Ltd. It contains information about FDI projects, the location, and the year of investment. The database is continually updated using media 
Table 3 Summary statistics: derivatives users versus non-users

\begin{tabular}{|c|c|c|c|c|c|c|}
\hline \multirow[t]{2}{*}{ Variables } & \multicolumn{2}{|c|}{ All firms } & \multirow{2}{*}{$\begin{array}{l}\text { Users } \\
\text { Mean }\end{array}$} & \multirow{2}{*}{$\begin{array}{c}\text { Non-users } \\
\text { Mean }\end{array}$} & \multirow{2}{*}{$\begin{array}{l}\text { Difference in means } \\
\text { Non-users - Users }\end{array}$} & \multirow[t]{2}{*}{$P$ value } \\
\hline & Obs & Mean & & & & \\
\hline \multicolumn{7}{|l|}{ Panel A: Domestic firm } \\
\hline EPU exposure & 3959 & 0.6226 & 0.5668 & 0.7628 & 0.196 & $0.040^{\star *}$ \\
\hline FX risks exposure & 3959 & 0.1468 & 0.1226 & 0.2642 & 0.1416 & $0.022^{* *}$ \\
\hline IR risks exposure & 3959 & 0.1228 & 0.5604 & 0.9068 & 0.3463 & $0.007^{* * *}$ \\
\hline Firm size & 4218 & 5.43 & 5.7169 & 5.1739 & -0.543 & $0.000^{* * *}$ \\
\hline Leverage & 4237 & 25.016 & 23.823 & 26.072 & 2.2484 & 0.309 \\
\hline FORSALES & 2952 & 41.836 & 42.566 & 41.147 & -1.4191 & 0.323 \\
\hline GEOMART & 3787 & 0.5147 & 0.5014 & 0.5263 & 0.0249 & 0.124 \\
\hline Diversification indicator & 4158 & 0.3942 & 0.4035 & 0.3857 & -0.0177 & 0.241 \\
\hline Tobin's Q & 4218 & 0.4556 & 0.5226 & 0.4252 & 0.0974 & $0.06^{*}$ \\
\hline Derivatives intensity & 4218 & 0.1565 & & & & \\
\hline \multicolumn{7}{|l|}{ Panel B: Domestic MNCs } \\
\hline EPU exposure & 4390 & 0.6224 & 0.4668 & 0.6558 & 0.189 & $0.001^{* * *}$ \\
\hline FX risks exposure & 4390 & 0.1822 & 0.1628 & 0.2246 & 0.0614 & $0.056^{*}$ \\
\hline IR risks exposure & 4390 & 0.5246 & 0.4226 & 0.6828 & 0.2602 & $0.001^{* *}$ \\
\hline Firm size & 4603 & 6.3791 & 7.0131 & 5.6861 & -1.326 & $0.000^{* * *}$ \\
\hline Leverage & 4620 & 23.754 & 22.89 & 24.697 & 1.8069 & 0.137 \\
\hline FORSALES & 3219 & 31.995 & 32.842 & 30.83 & -2.0124 & 0.091 * \\
\hline GEOMART & 4368 & 0.7704 & 0.785 & 0.7549 & -0.03 & $0.018^{* *}$ \\
\hline Diversification indicator & 4565 & 0.5301 & 0.5454 & 0.5131 & -0.0322 & $0.068^{*}$ \\
\hline Tobin's Q & 4603 & 0.6228 & 0.8116 & 0.4226 & 0.389 & $0.001^{* * *}$ \\
\hline Derivatives intensity & 4603 & 0.1627 & & & & \\
\hline \multicolumn{7}{|l|}{ Panel C: Foreign affiliates } \\
\hline EPU exposure & 679 & 0.6828 & 0.6226 & 0.6557 & 0.0331 & 0.043 \\
\hline FX risks exposure & 679 & 0.2577 & 0.2256 & 0.2488 & 0.0232 & 0.967 \\
\hline IR risks exposure & 679 & 0.9226 & 0.8776 & 0.9826 & 0.115 & $0.076^{\star \star}$ \\
\hline Firm size & 704 & 5.4215 & 5.6719 & 5.2502 & -0.4216 & $0.015^{\star *}$ \\
\hline Leverage & 702 & 29.937 & 24.466 & 33.699 & 9.2331 & 0.431 \\
\hline FORSALES & 507 & 34.418 & 36.44 & 32.752 & -3.688 & 0.245 \\
\hline GEOMART & 675 & 0.6592 & 0.6212 & 0.6836 & 0.0624 & $0.098^{*}$ \\
\hline Diversification indicator & 704 & 0.4218 & 0.3298 & 0.4866 & 0.1567 & $0.000^{* * *}$ \\
\hline Tobin's Q & 704 & 0.7146 & 0.7156 & 0.7225 & -0.0069 & 0.11 \\
\hline Derivatives intensity & 704 & 0.1488 & & & & \\
\hline
\end{tabular}

Note: This table presents the summary statistics of characteristics for firms that use derivatives and firms that do not. Panel A reports summary statistics for the variables for the domestic firms. Panel B displays the mean, standard deviation for variables of domestic MNCs, only separately for derivatives users and non-users. Panel $\mathrm{C}$ presents these values for foreign affiliates only. $\boldsymbol{p}$ values for testing the difference in mean are also reported. Asterisks $* * *, * *$, and * indicate significance at the 1, 5, and $10 \%$ level, respectively.

announcements of cross-border greenfield investments covering all sectors and countries worldwide. For the current article, we are interested in firms being originated in 8 countries and also investing in 8 countries of our study. Further, we focus on domestic MNEs in our sample.

In line with Duanmu (2014), we implement the following model specification:

$$
F D I_{i h s t+1}=\beta+\beta_{1} \frac{E P U_{h s t}}{E P U_{f s t}}+\beta X_{i h s t}+\chi C_{k s t}+\varepsilon_{i k s t} .
$$

This specification models the scale of FDI by firm $\mathrm{i}$ in the home country $\mathrm{h}$ in the year $\mathrm{t}-F D I_{\text {ihst }+1}$.
The s term is an index for the industry classification. The $\mathrm{f}$ term is an index for the host country.

Dependent variable FDI is measured by the natural log of the amount of investment (million US\$).

Independent variable $\frac{E P U_{h s t}}{E P U_{f s t}}$ represents the relative EPU of home (h) to host country (f).

$X_{\text {ihst }}$ is a vector of firm specifics defined above.

$C_{k s t}$ is a vector control variable including the natural log of the GDP per head in current US\$, proportion of total unemployment, natural resource measured by the percentage of metal and ore in country's total export, real exchange rate, and distance as measured by the natural log of 
Table 4 Linking EPU and firm-level FDI

\begin{tabular}{|c|c|c|c|}
\hline & Model 1 & Model 2 & Model 3 \\
\hline \multirow[t]{2}{*}{ EPU home/EPU host (EPU ratio) } & $0.026^{* * *}$ & $0.022^{* * *}$ & $0.016^{\star * *}$ \\
\hline & $(0.001)$ & $(0.005)$ & $(0.008)$ \\
\hline \multirow[t]{2}{*}{ Rule of law } & & $0.011^{*}$ & $0.115^{\star}$ \\
\hline & & $(0.06)$ & $(0.076)$ \\
\hline \multirow[t]{2}{*}{ Index of financial market development } & & 0.005 & 0.008 \\
\hline & & $(0.24)$ & $(0.10)$ \\
\hline \multirow{2}{*}{ Global economic uncertainty } & & 0.002 & $0.08^{*}$ \\
\hline & & $(0.17)$ & $(0.08)$ \\
\hline \multirow[t]{2}{*}{ Distance between home and host } & & & 0.118 \\
\hline & & & $(0.16)$ \\
\hline \multirow[t]{2}{*}{ Log (GDP per capita ratio) } & & $0.046^{*}$ & $0.056^{*}$ \\
\hline & & $(0.025)$ & $(0.02)$ \\
\hline \multirow[t]{2}{*}{ Log(GDP per capita ratio) $\times$ EPU ratio } & & $0.026^{*}$ & 0.016 \\
\hline & & $(0.06)$ & $(0.11)$ \\
\hline \multirow[t]{2}{*}{ Corporate total tax } & & & $(0.005)$ \\
\hline & & & $(0.11)$ \\
\hline Natural resource & & & 0.005 \\
\hline \multirow[t]{2}{*}{ Exchange rate } & & & $(0.155)$ \\
\hline & & & $0.010^{*}$ \\
\hline Control for firm specifics & Yes & Yes & Yes \\
\hline Industry fixed effect & Yes & Yes & Yes \\
\hline Year fixed effect & Yes & Yes & Yes \\
\hline No. of observations & 856 & 856 & 856 \\
\hline Adjusted R-squared & 0.22 & 0.25 & 0.32 \\
\hline
\end{tabular}

Note: ${ }^{\dagger}$ if $\mathrm{p}<0.10{ }^{*}$ if $\mathrm{p}<0.05 ;{ }^{* *}$ if $\mathrm{p}<0.01$; ${ }^{* *}$ if $\mathrm{p}<0.001$. We use the S\&P 500 volatility index (VIX) to proxy for global policy uncertainty. Firm specifics include variables listed in Table 1. Firm-specific variables include firm age, fixed asset, and profitability.

distance between home's capital and host's capital city.

Table 4 presents the relationship between FDI and its determinants. The correlations between FDI and its determinants are mostly in the expected directions (see Duanmu, 2014). The key finding is the positive correlation between the ratio of EPU at home to EPU at host country $(\beta=0.016, p<0.008)$. Firms are more likely to make FDI in countries, which have a low level of EPU relative to their home state. This result remains unchanged when we include firm specifics and other macroeconomic variables - as well as the year and industry fixed effects. Our findings are in line with Tallman (1988), Grosse and Trevino (1996), Duanmu (2014) who note a significant link between FDI and relative political risk between home and host countries.

Overall, the results confirm Hypothesis 1 on the positive relationship between the ratio of EPU in home to host country and firm-level FDI.

\section{Linking EPU and Firm Hedging Behavior}

Next, we conduct a multivariate analysis to explore the link between EPU and derivatives use. We implement the following model specifications:

$$
\frac{\text { Derivative }_{i, j, t}}{\mathrm{TA}_{i, j, t-1}}=\alpha_{i}+\beta \mathrm{EPU}_{j, t}+\gamma X_{i, t}+\delta M_{j, t}+\varepsilon_{i, j, t}
$$

where Derivative ${ }_{i, t}$ is the amount of derivative that firm $i$ uses in year $t .{ }^{14}$ In line with existing literature (Aretz \& Bartram, 2010), we focus on the most important type of derivatives: hedging against exchange rate risk.

$\mathrm{TA}_{i, t-1}$ is firm $i$ 's total asset in year $t-1$, and $E P U_{j, t}$ is the policy uncertainty index for firms located in country $j$. As such, $\frac{\text { Derivative }_{i, j, t}}{\mathrm{TA}_{i, t-1}}$ is a measure for intensity in derivatives use.

$\alpha_{i}$ is the firm's fixed effect, $M_{j, t}$ is a vector of country j's specific variables defined above, and $X_{i, t}$ is a vector of firm-specific variables defined above.

Following literature on pure cluster sampling, we assume that the error term $\varepsilon_{i, j, t}$ contains a common country effect that can be separated in an additive fashion, as in $\varepsilon_{i, j, t}=c_{j, t}+u_{i, j, t}$, where $c_{j, t}$ is an unobserved cluster (country) effect and $u_{i, j, t}$ is the idiosyncratic error.

As in Wooldridge (2003), our model specification can be referred to as a hierarchical linear model (HLM). We cluster standard errors at the country level to correct for potential cross-sectional and serial 
Table 5 Determinants for the intensity of derivatives use

\begin{tabular}{|c|c|c|}
\hline & Model 1 & Model 2 \\
\hline \multirow[t]{2}{*}{ Firm size } & $0.028^{* * *}$ & $0.032^{* * *}$ \\
\hline & $(0.001)$ & $(0.0008)$ \\
\hline \multirow[t]{2}{*}{ Leverage } & $0.011^{\star * *}$ & $0.017^{* \star *}$ \\
\hline & $(0.007)$ & $(0.005)$ \\
\hline \multirow[t]{2}{*}{ Interest coverage } & 0.004 & 0.005 \\
\hline & $(0.157)$ & $(0.176)$ \\
\hline \multirow[t]{2}{*}{ Capital expenditure } & 0.022 & 0.028 \\
\hline & $(0.168)$ & $(0.107)$ \\
\hline \multirow[t]{2}{*}{ Quick ratio } & 0.0556 & 0.0188 \\
\hline & $(0.102)$ & $(0.100)$ \\
\hline \multirow[t]{2}{*}{ Dividend yield } & 0.0565 & 0.076 \\
\hline & $(0.157)$ & $(0.102)$ \\
\hline \multirow[t]{2}{*}{ FORSALE } & 0.020 & 0.028 \\
\hline & $(0.146)$ & $(0.116)$ \\
\hline \multirow[t]{2}{*}{ GEOMART } & $0.0258^{* *}$ & $0.0256^{* *}$ \\
\hline & $(0.0015)$ & $(0.026)$ \\
\hline \multirow[t]{2}{*}{ Diversification indicator } & 0.046 & 0.0576 \\
\hline & $(0.147)$ & $(0.104)$ \\
\hline \multirow{2}{*}{ Cross-listed } & 0.017 & 0.0016 \\
\hline & $(0.224)$ & $(0.248)$ \\
\hline \multirow[t]{2}{*}{ GDP per capita } & & 0.276 \\
\hline & & $(0.167)$ \\
\hline \multirow[t]{2}{*}{ DEPOSITSTOGDP } & & 0.011 \\
\hline & & $(0.106)$ \\
\hline Industry's fixed effect & Yes & Yes \\
\hline \multirow[t]{2}{*}{ Constant } & 2.26 & 2.76 \\
\hline & $(1.84)$ & $(1.76)$ \\
\hline No. of observations & 3123 & 3123 \\
\hline No. of firms & 881 & 881 \\
\hline Adjusted R-squared & 0.42 & 0.48 \\
\hline
\end{tabular}

Note: The dependent variable is measured as the notional amount of derivatives use divided by total assets. Given that the dependent variable is censored at zero we use the Tobit model. All independent variable definitions are reported in Table 1 . The coefficients and significance levels are reported for each model. Policy sensitive sectors include sensitive defense, healthcare, and construction. $p$ values are in parentheses with standard errors clustered by countries.

${ }^{\dagger}$ if $p<0.10$, * if $p<0.05 ;{ }^{* *}$ if $p<0.01 ;{ }^{* * *}$ if $p<0.001$.

correlation in the error term (Petersen, 2009). Further, considering the small number of countries in our sample, we follow closely Cameron, Gelbach, and Miller (2008) to implement the wild cluster bootstrap-t procedure. It is a bootstrap that relaxes some restrictions of the more obvious resampling with replacement procedures. Cameron et al. (2008) show that this procedure performs well even when the number of clusters is as few as six. ${ }^{15}$ In addition, in all specifications we include industry and year fixed effects. Taking into consideration that some sectors are more sensitive to defense, healthcare, and construction policymaking, we run the regression incorporating binary variables to represent these factors. Some country-specific data - such as rule of law - were obtained from Transparency International and reports from central banks of sample countries; proxies for governance mechanisms were obtained from the World Bank. All financial data are measured in years and thousands of USD.

Table 5 presents the main findings of our basic model. In the baseline Model 1, we explore the effect of policy uncertainty on derivative use intensity - controlling for firm-specific variables. Most important for our purpose, we find that policy uncertainty is significantly associated with the firm's intensity of derivatives use $(p<0.01)$. The positive impact of the policy uncertainty index on the intensity of derivatives use indicates that greater uncertainty in economic policy increases firm exposure to risks, thus increasing the incentive to use derivatives. 


\section{Extending the Baseline Model}

\section{The role of institutional quality and financial markets development}

This section explores whether the effect of policy uncertainty on derivatives use remains significant, even after controlling for the effect of a country's institution quality. To measure institution quality, we use the rule of law index. ${ }^{16}$ As noted from Table 5, Model 2, institution quality shows a marginal effect on firm hedging behavior. Finally, it is worth noting that integrating institution quality into the model sustains the significant effect of policy uncertainty on a firm's hedging behavior.

Another important macro variable that may influence firm hedging behavior is the level of financial markets. Better developed financial markets motivate firms to use derivatives more. To address this concern, we use the Global Financial Development Database, which is an extensive dataset of financial system characteristics for 203 economies. ${ }^{17}$ Building upon Čihák, Demirgüç-Kunt, Feyen, and Levine (2012), we develop an index of financial market development and incorporate the following four elements: the size of financial institutions and markets (financial depth), the degree to which individuals can and do use financial services (access), the efficiency of financial intermediaries and markets in intermediating resources and facilitating financial transactions (efficiency), and the stability of financial institutions and markets (stability).

We then examine whether the effect of EPU on derivatives use is still significant, even after controlling for this index. Table 5, column 3 indicates that
EPU still plays a significant role in driving a firm's hedging behavior. The effect of the financial market development, however, is not significant at any conventional level. This finding confirms the significant link between EPU and firm hedging behavior.

\section{Other Macroeconomic Variables}

One may wonder whether increases in policy uncertainty tend to coincide with other macro shocks and uncertainties, such as recessions, wars, and financial crises. In this case, the influence of a firm's specific and country-level variables may be captured by policy uncertainty, biasing its effect. In other words, the Baker et al. (2016) index may in fact capture - at least partially - the effect of other general sources of risk and uncertainty on derivatives use. To address this concern, we incorporate several variables into our main specification, which capture various aspects of macroeconomic conditions. In particular, we include in the model institutional quality, country/political risk, financial soundness indicators (FSIs), and the global policy uncertainty of our sample countries. ${ }^{18,19}$ Table 6 presents the main findings.

\section{EPU for Specific Types of Policies}

To complete this section, it is worth noting that the EPU index we have used so far aims to measure uncertainty in overall policy. We wonder whether uncertainty in particular types of policy drives more derivatives use. Given our focus on firm behavior to hedge against exchange rate risk, we are interested in policies that would affect the exchange rate. In particular, we expect that monetary policy, trade

Table 6 Determinants for the intensity of derivatives use-incorporating other macro uncertainties into the model specification

\begin{tabular}{|c|c|c|c|}
\hline & Model 1 & Model 2 & Model 3 \\
\hline \multirow[t]{2}{*}{ EPU index } & $0.228^{* *}$ & $0.276^{\star \star *}$ & $0.284^{* * *}$ \\
\hline & $(0.02)$ & $(0.008)$ & $(0.005)$ \\
\hline \multirow[t]{2}{*}{ Rule of law } & & $0.147^{*}$ & $0.122^{*}$ \\
\hline & & $(0.07)$ & $(0.09)$ \\
\hline \multirow[t]{2}{*}{ Index of financial market development } & & & $0.026^{*}$ \\
\hline & & & $(0.07)$ \\
\hline \multirow{2}{*}{ Global economic uncertainty } & & & $0.126^{*}$ \\
\hline & & & $(0.06)$ \\
\hline Control for firm specifics & Yes & Yes & Yes \\
\hline Industry fixed effect & Yes & Yes & Yes \\
\hline Year fixed effect & Yes & Yes & Yes \\
\hline No. of observations & 3123 & 3123 & 3123 \\
\hline
\end{tabular}

Note: The dependent variable is a continuous variable, which is measured as the notional amount of derivatives use divided by total assets. Given that the dependent variable is censored at zero we use the Tobit model. Non-derivative users are set to zero. All independent variable definitions are reported in Table 1. The coefficients and significance levels are reported for each model. $p$ values are in parentheses with standard errors clustered by countries We use the S\&P 500 volatility index (VIX) to proxy for global policy uncertainty. Firm specifics include variables listed in Table 1.

$\dagger$ if $\mathrm{p}<0.10{ }^{*}$ if $\mathrm{p}<0.05 ;{ }^{* *}$ if $\mathrm{p}<0.01 ;{ }^{* \star *}$ if $\mathrm{p}<0.001$. 
Table 7 Determinants for the intensity of derivatives use - by overall and specific EPU policy

\begin{tabular}{lllll}
\hline & Overall & Monetary policy & Exchange rate policy & Financial regulation \\
\hline EPU index & 0.28 & 0.26 & 0.34 & 0.226 \\
& $(0.006)^{\star * *}$ & $(0.007)^{\star \star *}$ & $(0.002)^{\star * *}$ & $(0.04)^{\star *}$ \\
Control for firm specifics & Yes & Yes & Yes & Yes \\
Industry fixed effect & Yes & Yes & Yes & Yes \\
Year fixed effect & Yes & Yes & Yes & Yes \\
No. of observations & 3123 & 3123 & 3123 & 3123
\end{tabular}

Note: We use the same model specification shown in Table 6, column 3. In column "Overall," we use the overall EPU to represent the EPU index. Other columns are defined likewise.

The dependent variable is a continuous variable measured as the notional amount of derivatives use divided by total assets. Non-derivative users are set to zero. All independent variable definitions are reported in Table 1 . The coefficients and significance levels are reported for each model. $p$ values are in parentheses with standard errors clustered by countries.

${ }^{\dagger}$ if $\mathrm{p}<0.10$, $^{*}$ if $\mathrm{p}<0.05^{* *}$ if $\mathrm{p}<0.01$; $^{* * *}$ if $\mathrm{p}<0.001$.

policy, and financial regulation would potentially affect exchange rate. Building upon the Baker et al. (2016) method of developing categorical EPU, we generate an EPU for monetary policy, exchange rate policy, and financial regulation, respectively. ${ }^{20}$ To do so, we use the same set of newspapers used to construct our general EPU. Next we derive the categorical EPUs. Each categorical EPU requires our economic, uncertainty, and policy terms as well as a set of categorical policy terms. For example, the EPU for exchange rate is generated by including articles that fulfill our requirements to be coded as EPU -i.e., they include our economic, uncertainty, and policy terms - as well as a set of the following terms: foreign exchange rate, forex rate, ER, FX rate, or Agio. For instance, articles that fulfill our requirements to be coded as EPU and also contain the term 'FX rate' would be included in the foreign exchange EPU.

We then explore whether these categorical EPU policies would have the same effect on firm hedging behavior as the overall EPU. Table 7 uses exactly the same model specification as shown in Table 6, column 3, thus incorporating institutional quality, financial market development, and other macro uncertainty-related variables. The only difference is that in addition to the overall EPU, we consider EPU for various types of policies that may affect exchange rate. The key insight we can derive from Table 7 is that the EPU index for each specific type of policy shows consistent and positive effects on firm hedging behavior. Further, these effects have almost the same magnitude as that of the overall EPU index.

In sum, we find that the explanatory power of the policy uncertainty index does not get absorbed by any of the other measures of aggregate uncertainty. This result stresses the role of policy uncertainty in driving a firm's hedging behavior. Furthermore, our policy uncertainty index - in the spirit of the Baker et al. (2016) index - contains information about macroeconomic uncertainty that is not captured by any of the existing measures used in the literature.

\section{Linking Derivatives Use, EPU Exposure, and Firm Performance}

In this section, we implement the market model building upon Adler and Dumas (1984) and Jorion (1990) - to estimate firms' level of exposure to EPU. We then explore whether derivatives use is an efficient instrument to hedge against EPU exposure and improve firm performance. In doing so, we investigate whether using derivatives enables firms to address EPU exposure more efficiently, in terms of reducing the effect of EPU on firm performance.

\section{Stage one: Exposure estimation}

In line with existing studies (e.g., Allayannis \& Ofek, 2001; Hutson \& Stevenson, 2010), we apply the two-stage approach. In the first stage, we estimate firm exposure to EPU using the Adler and Dumas (1984) market model. In the second stage, we explore the relationship between derivatives use and EPU exposure. The dependent variables are the coefficients that are estimated by the market model $^{21}$ in the first stage.

We use the total monthly sample from January 2003 to December 2013 to estimate the augmented market model (cross-sectional) regressions. ${ }^{22}$ For individual firms, we calculate stock returns in USD, the USD returns of the corresponding national stock market index, the EPU index, the percentage change in trade-weighted effective exchange rate (in local currency relative to one unit of USD), and interest rates. We use the one-year Interbank offered rate, which is compounded monthly, in the data for each country obtained from Datastream as a proxy for interest rate. 
In particular, we estimate for each firm in the following equations:

$$
R_{i j t}=\beta_{0 i}+\lambda_{i j t} \mathrm{EPU}_{j t}+\beta_{1 i j t} R_{m j t}+\varepsilon_{i j t}
$$

where $R_{i j t}$ is the rate of return on stock of firm $i$ located in country $j$ in period $t, R_{m j t}$ is the rate of return on country $j$ 's benchmark stock index in period $t$, and $\varepsilon_{i t t}$ is the error term clustered by country.

The coefficients $\lambda_{i j t}$ represent exposure to EPU. In line with Allayannis and Ofek's (2001) definition of exchange rate exposure, we define exposure to EPU as the percentage change in the rate of return on a firm's common stock against a $1 \%$ change in the EPU index.

Likewise, we estimate the exchange rate exposure and the exposure to interest rates in the same manner.

\section{Stage two: Model estimated exposure}

In the second stage, we explore the potential effects of firms' derivatives use on exposure to EPU. In particular, we use the estimated exposure coefficients in the first stage as the dependent variables in multivariate analysis as follows: ${ }^{23}$

$$
\hat{\lambda}_{i j t}=\theta_{0}+\theta_{1} \text { Derivatives }_{i j t}+\chi X_{i j t}+\eta C_{i j t}+\varepsilon_{i j t}
$$

where $\hat{\lambda}_{i j t}$ is the value of exposure to EPU estimated from the first stage of firm $i$ located in country $j$ in year $t, D_{i j t}$ is the intensity of derivative use for firm $i$ in year $t, X_{i j t}$ is the vector of firm-specific variables in year $t$, including operational hedging, international involvement, firm size, and leverage, $C_{i j t}$ is the country-level variable (GDP per capita, financial system deposits to GDP, and rule of law), and $\varepsilon_{i j t}$ is the error term clustered by country.

Table 8 presents the key findings of the estimation. In exploring the relationship between derivatives and exposure to EPU, we uncover some interesting results. For domestic firms, we observe that the derivatives use variable is significant and negatively related to exposure to EPU ( $\beta=-0.156, p<0.002)$, which implies that firms using derivatives reduce exposure by $15.6 \%$ for each $1 \%$ increase in the notional value of derivatives. Likewise, in the case of domestic MNCs, we find a negative relationship between exposure to EPU and derivatives use, which is higher than domestic firms. Interestingly, for foreign affiliates, we do not find any evidence of a significant relationship between derivatives use and exposure to host country EPU, though derivatives use has a negative effect on exposure. In general, the overall results reported in panel A support Hypothesis 4 . For domestic firms, we also observe that the derivatives use variable is significant and negatively related to exposure to EPU. Regarding domestic MNCs, exposure to country risks decreases when the general derivatives notional amount increases. For foreign affiliates, however, we do not find any evidence supporting a relationship between derivatives use and exposure to host country EPU, though derivatives use has a negative effect on exposure.

\section{Linking EPU and Firm Performance}

From the previous section, it can be found that corporate derivatives use reduces firms' exposure to EPU. An equally interesting question relates to the role of derivatives use in firm performance. To address this question, we implement the following model specification: ${ }^{24}$

$$
\begin{aligned}
\ln G_{i j t}= & \alpha_{i}+\alpha_{e p u} \ln \mathrm{EPU}_{j t}+\alpha_{d} D_{i j t}+\lambda_{e p u_{-} d} \mathrm{EPU}_{j t} * D_{i j t} \\
& +\alpha_{X} X_{i j t}+\varepsilon_{i j t} \varepsilon_{i, j, t}=c_{j, t}+u_{i, j, t}
\end{aligned}
$$

where $G_{i j t}$ is the performance of firm $i$ in year $t$ measured by Tobin's Q - located in country $j, D_{i j t}$ is the intensity of derivatives use for firm $i$ in year $t$, and $X_{i j t}$ is a vector of firm-specific variables in year $t$, including capital expenditures and number of employees with a degree.

In line with Allayannis and Weston (2001), we measure firm performance using Tobin's Q (in natural logarithm).$^{25}$ Please refer to Appendix D for further discussion on our approach to estimate Tobin's Q for firms in our sample. Table 9 presents the main results. The relationship between firm performance and independent variables is in expected directions. Interestingly, we find a negative correlation between cross-listing and firm value. The negative relationship between crosslisting and firm value is in line with the finding of Cetorelli and Peristiani (2015) that firms that use cross-listing in a less prestigious market experience a significant decline in valuation over the five years following the listing. Most relevant to our purpose, we find that EPU has a negative effect on firm performance. The magnitude of this effect is greatest among domestic firms $(\beta=-0.154, p<0.005)$.

Next, we explore whether firms can reduce the negative effect of EPU on performance using derivatives more intensively. We notice a significant and positive effect of the interaction term for all firm types, especially domestic MNCs $(\beta=0.0657, p<0.002)$. This finding suggests that 
Table 8 Exposure and derivatives use

\begin{tabular}{|c|c|c|c|}
\hline Variables & Domestic firms & Domestic MNCs & Foreign affiliates \\
\hline \multicolumn{4}{|c|}{ Panel A: Exposure to country EPU } \\
\hline \multirow[t]{2}{*}{ Derivative use } & $-0.156^{\star \star *}$ & $-0.168^{* * *}$ & -0.026 \\
\hline & $(0.002)$ & $(0.001)$ & $(0.226)$ \\
\hline \multirow[t]{2}{*}{ Firm size } & -1.22 & $-0.482^{\star *}$ & -0.262 \\
\hline & $(0.202)$ & $(0.022)$ & $(0.157)$ \\
\hline \multirow[t]{2}{*}{ Leverage } & -0.028 & -0.0186 & 0.056 \\
\hline & $(0.268)$ & $(0.466)$ & $(0.122)$ \\
\hline \multirow[t]{2}{*}{ FORSALES } & 0.056 & $0.0276^{\star}$ & $0.128^{\star *}$ \\
\hline & $(0.126)$ & $(0.076)$ & $(0.012)$ \\
\hline \multirow[t]{2}{*}{ GEOMART } & -0.276 & -0.488 & 0.206 \\
\hline & $(0.226)$ & $(0.125)$ & $(0.112)$ \\
\hline \multirow[t]{2}{*}{ Cross-listed } & -0.535 & -0.488 & -0.546 \\
\hline & $(0.206)$ & $(0.146)$ & $(0.228)$ \\
\hline \multirow[t]{2}{*}{ GDP per capita } & 0.206 & 0.225 & $0.656^{\star *}$ \\
\hline & $(0.266)$ & $(0.116)$ & $(0.011)$ \\
\hline \multirow[t]{2}{*}{ DEPOSITSTOGDP } & $-0.112^{* *}$ & -0.115 & $-0.062^{*}$ \\
\hline & $(0.042)$ & $(0.125)$ & $(0.084)$ \\
\hline \multirow[t]{2}{*}{ Rule of law } & 3.225 & 8.56 & $-0.224^{\star}$ \\
\hline & $(0.426)$ & $(0.228)$ & $(0.056)$ \\
\hline \multirow[t]{2}{*}{ Intercept } & 10.22 & 12.58 & $18.28^{* *}$ \\
\hline & $(0.466)$ & $(0.168)$ & $(0.016)$ \\
\hline Country dummies & Yes & Yes & Yes \\
\hline Industry dummies & Yes & Yes & Yes \\
\hline Year dummies & Yes & Yes & Yes \\
\hline No. of observations & 2007 & 1136 & 198 \\
\hline R-square & 0.40 & 0.42 & 0.38 \\
\hline \multicolumn{4}{|l|}{ Panel B: FX exposure } \\
\hline \multirow[t]{2}{*}{ FCD } & $-0.112^{* * *}$ & $-0.176^{\star}$ & -0.122 \\
\hline & $(0.002)$ & $(0.064)$ & $(0.848)$ \\
\hline \multirow{2}{*}{ Firm size } & $-0.146^{*}$ & -0.224 & -0.158 \\
\hline & $(0.076)$ & $(0.122)$ & $(0.226)$ \\
\hline \multirow[t]{2}{*}{ Leverage } & -0.0122 & $-0.028^{\star}$ & 0.076 \\
\hline & $(0.422)$ & $(0.010)$ & $(0.155)$ \\
\hline \multirow[t]{2}{*}{ FORSALES } & 0.022 & 0.028 & 0.028 \\
\hline & $(0.566)$ & $(0.158)$ & $(0.288)$ \\
\hline \multirow[t]{2}{*}{ GEOMART } & 0.226 & -0.022 & 0.226 \\
\hline & $(0.284)$ & $(0.157)$ & $(0.206)$ \\
\hline \multirow[t]{2}{*}{ Cross-listed } & 0.156 & -0.035 & 0.225 \\
\hline & $(0.226)$ & $(0.122)$ & $(0.428)$ \\
\hline \multirow[t]{2}{*}{ GDP per capita } & $0.228^{* * *}$ & $0.256^{*}$ & 0.112 \\
\hline & $(0.002)$ & $(0.001)$ & $(0.106)$ \\
\hline DEPOSITSTOGDP & $-0.422^{* * *}$ & $-0.026^{\star *}$ & $-0.101^{* *}$ \\
\hline & $(0.006)$ & $(0.022)$ & $(0.025)$ \\
\hline Rule of law & $-0.225^{\star}$ & 0.205 & -0.256 \\
\hline & $(0.052)$ & $(0.116)$ & $(0.422)$ \\
\hline Intercept & $-2561^{* * *}$ & $-2645^{*}$ & -2255 \\
\hline & $(0.001)$ & $(0.072)$ & $(0.112)$ \\
\hline Country dummies & Yes & Yes & Yes \\
\hline Industry dummies & Yes & Yes & Yes \\
\hline Year dummies & Yes & Yes & Yes \\
\hline No. of observations & 1053 & 1250 & 410 \\
\hline Adjusted R-square & 0.224 & 0.256 & 0.268 \\
\hline Panel C: IR exposure & & & \\
\hline IRD & $-0.284^{* \star *}$ & $-0.225^{*}$ & $-0.215^{*}$ \\
\hline & $(0.002)$ & $(0.076)$ & $(0.076)$ \\
\hline
\end{tabular}


Table 8 (Continued)

\begin{tabular}{|c|c|c|c|}
\hline Variables & Domestic firms & Domestic MNCs & Foreign affiliates \\
\hline \multirow[t]{2}{*}{ Firm size } & -0.026 & $-0.084^{*}$ & -0.068 \\
\hline & $(0.226)$ & $(0.052)$ & $(0.122)$ \\
\hline \multirow[t]{2}{*}{ Leverage } & $-0.026^{* *}$ & -0.015 & $-0.042^{* *}$ \\
\hline & $(0.026)$ & $(0.211)$ & $(0.045)$ \\
\hline \multirow[t]{2}{*}{ FORSALES } & $0.076^{* *}$ & 0.068 & 0.055 \\
\hline & $(0.026)$ & $(0.566)$ & $(0.682)$ \\
\hline \multirow[t]{2}{*}{ GEOMART } & 0.022 & -0.226 & 0.256 \\
\hline & $(0.565)$ & $(0.152)$ & $(0.226)$ \\
\hline \multirow[t]{2}{*}{ Cross-listed } & 0.134 & -0.100 & -0.321 \\
\hline & $(0.630)$ & $(0.373)$ & $(0.290)$ \\
\hline \multirow[t]{2}{*}{ GDP per capita } & -0.119 & -1.639 & -1.729 \\
\hline & $(0.905)$ & $(0.234)$ & $(0.509)$ \\
\hline \multirow[t]{2}{*}{ DEPOSITSTOGDP } & $-0.046^{\star}$ & $-0.024^{\star *}$ & $-0.028^{\star *}$ \\
\hline & $(0.062)$ & $(0.016)$ & $(0.025)$ \\
\hline \multirow[t]{2}{*}{ Rule of law } & -0.582 & -0.147 & -0.225 \\
\hline & $(0.156)$ & $(0.124)$ & $(0.146)$ \\
\hline \multirow[t]{2}{*}{ Intercept } & -2.25 & -8.24 & 2.46 \\
\hline & $(0.56)$ & $(0.22)$ & $(0.46)$ \\
\hline Country dummies & Yes & Yes & Yes \\
\hline Industry dummies & Yes & Yes & Yes \\
\hline Year dummies & Yes & Yes & Yes \\
\hline No. of observations & 591 & 2398 & 430 \\
\hline R-square & 0.42 & 0.46 & 0.40 \\
\hline
\end{tabular}

Note: This table reports the effects of derivatives use on exposure across domestic firms, MNCs, and foreign affiliates from pooled regression models split up with regard to exposure to EPU, exchange rate, and interest rate risks. The dependent variables are absolute values of exposure to EPU (panel A), exchange rate risks (panel B), and interest rate risks (panel C). Derivatives use is the notional value of any derivative contracts in thousands of USD, scaled by total assets. FCD is the notional value of foreign currency derivatives in thousands of USD, scaled by total assets. IRD is the notional value of interest rate derivatives in thousands of USD, scaled by total assets. $p$ values are in parentheses. Asterisks ***, ${ }^{* *}$, and * indicate significance at the 1,5 , and $10 \%$ level, respectively.

intensifying the use of derivatives enables firms to address the negative effect of EPU more efficiently, which supports Hypothesis 3B.

\section{EPU Exposure and the use of derivatives across time -} in pre-crisis, during-crisis, and post-crisis periods

Given the close relationship between EPU and the global financial crisis of 2007-2008 (Baker et al., 2016), we are interested in the link between derivatives use and EPU exposure in this context. It has been well established that firms may be exposed to two separate and sequential effects of a crisis. On the one hand, faced with sudden and major external shocks, firms have difficulty adjusting their risk management activities to mitigate contagion risks during a crisis period (Syriopoulos, Makram, \& Boubaker, 2015). On the other hand, when causes and consequences of a crisis become more obvious, firms restructure to adjust to a new environment and reduce risk to EPU exposure. Therefore, we expect that the effect of derivatives use on EPU exposure is likely to be worse during the crisis period, but will improve in the post-crisis period.
Table 10 presents exposure to EPU in relation to crisis periods. Before the onset of the global financial crisis, we observe a significant negative relationship between derivatives use and exposure to home country risks in the case of domestic firms, and domestic MNCs. Interestingly, derivatives use is found to be insignificant at any standard level for foreign affiliates, though it is inversely associated with exposure to host country EPU.

During the crisis period, we can observe that derivatives hedging becomes less effective in reducing EPU exposure of domestic firms and foreign affiliates. For domestic MNCs, the use of derivatives shows a significant negative association with exposure to home country risks, but the effect is modest in magnitude. These findings are related to the Allayannis, Brown, and Klapper (2003) observation of selective hedging among most East Asian, nonfinancial firms. In times of financial crisis, market price and indexes are largely unpredictable in the short term and display highly increased volatility around the crisis, thus decreasing the effect of derivatives hedging. Yet the situation changes in 
Table 9 Derivatives use moderates the relationship between EPU and firm performance

\begin{tabular}{|c|c|c|c|}
\hline Variables & Domestic firms & Domestic MNCs & Foreign affiliates \\
\hline \multirow[t]{2}{*}{ Derivatives use } & $0.0528^{* *}$ & $0.0466^{*}$ & $0.064^{*}$ \\
\hline & $(0.029)$ & $(0.057)$ & $(0.08)$ \\
\hline \multirow[t]{2}{*}{ Derivative $\times$ EPU } & $0.0657^{* *}$ & $0.0758^{* * *}$ & $0.0280^{*}$ \\
\hline & $(0.002)$ & $(0.001)$ & $(0.062)$ \\
\hline \multirow[t]{2}{*}{ EPU index } & $-0.154^{\star \star *}$ & $-0.129^{\star * *}$ & -0.0828 \\
\hline & $(0.005)$ & $(0.008)$ & $(0.134)$ \\
\hline \multirow[t]{2}{*}{ Firm size } & $0.945^{* * *}$ & $0.202^{* * *}$ & $0.804^{* * *}$ \\
\hline & $(0.000)$ & $(0.001)$ & $(0.001)$ \\
\hline \multirow[t]{2}{*}{ Leverage } & $0.0719^{\star *}$ & $0.0651^{*}$ & -0.0906 \\
\hline & $(0.019)$ & $(0.081)$ & $(0.112)$ \\
\hline \multirow{2}{*}{ Capital expenditure } & 0.0307 & $0.0304^{\star \star}$ & -0.0885 \\
\hline & $(0.242)$ & $(0.015)$ & $(0.836)$ \\
\hline \multirow[t]{2}{*}{ Cross-listed } & -0.0612 & -0.0264 & $-0.0119^{\star * *}$ \\
\hline & $(0.647)$ & $(0.127)$ & $(0.002)$ \\
\hline \multirow[t]{2}{*}{ Dividend yield } & -0.0104 & $0.0306^{\star *}$ & 0.0149 \\
\hline & $(0.577)$ & $(0.014)$ & $(0.256)$ \\
\hline \multirow[t]{2}{*}{ FORSALE } & $-0.0466^{*}$ & 0.0350 & -0.0685 \\
\hline & $(0.077)$ & $(0.643)$ & $(0.994)$ \\
\hline \multirow[t]{2}{*}{ GEOMART } & -0.211 & 0.0335 & 0.0913 \\
\hline & $(0.166)$ & $(0.570)$ & $(0.776)$ \\
\hline \multirow[t]{2}{*}{ Diversification indicator } & -0.0566 & -0.0578 & $-0.835^{* *}$ \\
\hline & $(0.747)$ & $(0.289)$ & $(0.013)$ \\
\hline \multirow[t]{2}{*}{ GDP per capita } & 0.0676 & -0.6170 & $0.479^{\star *}$ \\
\hline & $(0.967)$ & $(0.188)$ & $(0.010)$ \\
\hline \multirow[t]{2}{*}{ DEPOSITSTOGDP } & 0.0033 & $-0.0038^{*}$ & 0.0069 \\
\hline & $(0.883)$ & $(0.091)$ & $(0.261)$ \\
\hline \multirow[t]{2}{*}{ Intercept } & -2.915 & 3.472 & $-62.01^{* * *}$ \\
\hline & $(0.812)$ & $(0.422)$ & $(0.002)$ \\
\hline Country dummies & Yes & Yes & Yes \\
\hline Industry dummies & Yes & Yes & Yes \\
\hline Year dummies & Yes & Yes & Yes \\
\hline No. of observations & 1420 & 1431 & 272 \\
\hline R-square & 0.413 & 0.367 & 0.533 \\
\hline
\end{tabular}

Note: This table reports the effects of derivatives use on firm performance from an OLS estimation split up with regard to domestic firms, domestic MNCs, and foreign affiliates. The dependent variable is Ln (Tobin's Q), which is calculated as the natural logarithm of book value of total assets minus book value of equity plus the market value of equity over book value of total assets. Derivatives use is calculated as the notional value of derivative contracts in thousands of USD, scaled by total assets. Standard errors are clustered by country to control for heteroscedasticity and serial correlation. $p$ values are in parentheses. Asterisks ***, **, and * indicate significance at the 1, 5, and $10 \%$ level, respectively.

the post-crisis period, when the use of derivatives is more effective in reducing EPU exposure, irrespective of firm type. The estimated coefficients of derivatives use show a reduction in exposure to EPU, especially among domestic MNCs.

\section{MANAGERIAL IMPLICATIONS AND POTENTIAL FOR FUTURE RESEARCH}

Our study explores how firms behave in response to volatility in economic environments. Uncertainty in economic policies - regarding their timing, content, and impact - can make firm investments riskier, whereby future profitability becomes significantly more uncertain. Considering that derivatives are an important risk management instrument, we explore how uncertainty in economic policy is linked to firm performance and derivatives use. Our findings strongly suggest that greater policy uncertainty has a negative effect on the trajectory of firm growth and encourages firms to hedge more intensively. The policy uncertainty index is highly significant in all model specifications - in many cases it is the most significant determinant of derivatives use and firm performance. Interestingly, we find that using derivatives more intensively enables firms to hedge EPU more efficiently. Our finding is in line with extant literature (e.g., Kim et al., 2017) suggesting firms use derivatives as a risk management instrument. 


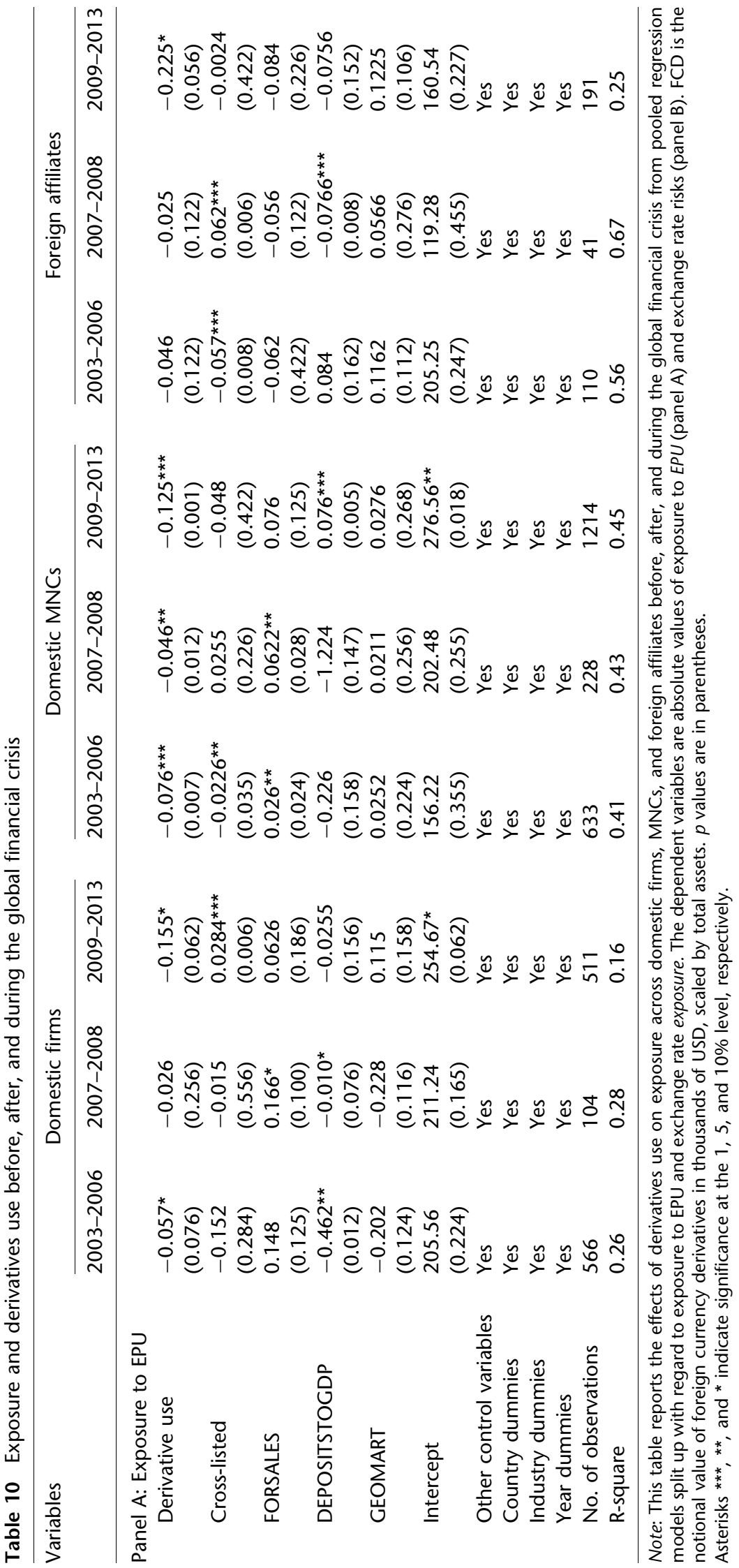


Overall, our study contributes to the literature by highlighting the importance of national policy uncertainty in driving firm hedging behavior. That the explanatory power of the policy uncertainty index is not absorbed by any other measures of aggregate uncertainty suggests not only that policy uncertainty has an effect on firm performance and hedging behavior, but also that the Baker et al. (2016) EPU index contains information about macroeconomic uncertainty not captured by any of the existing measures used in the literature. A potential direction for future research could cover a broader range of countries with more heterogeneous economic uncertainty; heterogeneity will allow researchers to further explore the effect of policy uncertainty on firm behaviors, including derivatives use.

\section{Managerial Implication}

Our study also has direct practical and meaningful implications for firm managers on decisions related to capital structure. In particular, the research provides new evidence that in East Asian countries EPU has a negative effect on firm performance; yet derivatives use is effective in reducing exposure to home country EPU. These findings suggest that firms could influence the cost of capital in particular, and capital structure in general by the use of financial derivatives, and thus firm managers better perform the important tasks of strategic capital planning and managing risks.

Despite our significant contributions to the growing body of research on derivatives use and exposure, this research has several limitations.

First, our sample consists of countries with great variances regarding the level of institutional and economic development. On the one hand, the robust results on the link between EPU, EPU exposure, and firm performance - after controlling for country's heterogeneity - prove that our findings can be useful in various environments. On the other hand, substantial differences exist among these countries in terms of derivatives use, firm scale, and multinational corporations, which makes us wonder whether our study implications are consistent and applicable for all of these countries. A potential direction for future studies is to conduct a more in-depth comparable study on the link between EPU exposure, derivatives use, and firm performance. In doing so, could we explicitly estimate the role of culture and institutional quality in moderating the relationship between EPU exposure, derivatives use, and firm performance by firm type.

Secondly, we estimate the derivative intensity using the notional value of derivative contracts held by each firm. We did so because sample firms are not required to report detailed information on specific positions of notional holdings, regarding derivatives holdings disclosures. Although total notional value effectively measures derivative ownership, more details on how firms actually use derivatives would be helpful. For example, a firm might state that they use a certain amount of money for foreign currency hedging. If so, it would be interesting to know if this is actually related to transfer pricing, or other motives. If data are available, future research should address these issues not only in the context of countries from South East Asia but also for other groups of countries.

Third, while the number of sample foreign affiliates identifies the effects of derivatives use on exposure relatively well, a bigger sample could provide a better view and evidence on that effect. Thus, a potential direction for future research could cover a broader range of foreign affiliates in a wider range of countries, which will allow researchers to further explore the differences in the effects between foreign-owned firms and domestic-owned firms.

\section{ACKNOWLEDGEMENTS}

We would like to express our sincerest thanks to the editor David Reeb, five anonymous referees, Nick Bloom, and Steven Davis for their excellent insights to improve our article in many aspects!

\section{NOTES}

${ }^{1}$ Financial derivatives are defined as financial instruments whose prices are dependent on or derived from the value of other, more basic underlying variables (Hull, 2012: 1). An underlying variable is a marketrelated characteristic of the asset or liability that leads to an increase in value changes (Gastineau, Smith, and Todd, 2001). They can be equity shares, stocks, bonds, debentures, treasury bills, foreign currencies, interest rates, commodity prices, or different market indices, such as the stock market index or the consumer price index (Anderson \& Gupta, 2009). In this article, we focused on total derivatives, and the 
most common and widely practiced types of nonfinancial firms, i.e., foreign currency (Aretz \& Bartram, 2010). We also conduct an analysis with other types of derivatives, such as interest rates. It is worth noting that foreign currency derivatives are settled at a specific future date, and their values are derived from changes in foreign currencies.

${ }^{2}$ As in Frank Knight (1921), we define uncertainty as individuals' inability to forecast the likelihood of events happening. In contrast, Knight defined risk as people's known probability distribution over known events. For example, the outcome from flipping a coin is risky you can assign a $50 \%$ chance to heads and a $50 \%$ chance to tails for a fair toss. In this study, we refer to a single concept of uncertainty, although this will typically be a stand-in for both risk and uncertainty.

${ }^{3}$ More recent news about the rapid decline in Chinese stock prices from late June 2015 provides a practical example of how policy uncertainty may influence firm behavior. In response to concern about the equity bubble, the Chinese government launched a series of initiatives in the first half of 2015 that tightened the margin finance - the use of borrowed money to buy shares - after relaxing it during the previous five years. The restrictions culminated in a June 12 announcement of a new limit on the total amount of margin lending. The stock market reacted immediately and stock prices have fallen ever since. More than 1400 stocks - about half of all listed companies - suspended from trading. Hundreds of Chinese companies have withdrawn from the market, while retail investors have rushed to unwind leveraged bets on the market. Such responsive behavior from firms led to the loss of $\$ 3000$ billion from the value of all listed firms. ${ }^{3}$ As the Financial Times suggests, a firm's reluctance to participate in the market is likely related to new rules, making the growth outlook for China's economy appear more uncertain. Thus, we explore whether firms use derivatives more intensively in response to this uncertainty.

${ }^{4}$ The 2014 annual survey of the Future Industry Association reveals that trading in the Asia-Pacific region amounts to $\$ 7.25$ billion, accounting for about one-third of global trading volume.

${ }^{5}$ Our study is also related to rapidly growing literature on text search methods - using newspaper archives in particular - to measure a variety of outcomes. Examples include Gentzkow and Shapiro (2010); Hoberg and Phillips (2010); Boudoukh et al., (2013), and Alexopoulos and Cohen (2015). Our work suggests that newspaper text searches can yield useful proxies for economic and policy conditions stretching back several decades, which could be especially valuable in analyzing earlier eras and countries with fewer data sources.

${ }^{6}$ For example, Colombo (2013) finds that a one standard deviation shock to the US economic policy uncertainty index leads to a statistically significant fall in European industrial production and prices. Handley and Limao (2012) find that trade policy uncertainty delays firm entry, and Gulen and Ion (2015) find negative responses of corporate investment to the EPU index. Gunnemann (2014) develops a policy uncertainty index, which relates to the Baker et al. (2016) EPU index, and is based on over 60 million newspaper articles. The author finds that an increase in economic policy uncertainty appears to have a little impact on industrial production and unemployment across the various economies. Aastveit et al. (Aastveit, Natvik, \& Sola, 2013) explore the interactive effect of economic uncertainty and monetary policy on economic activities. They find that monetary policy shocks affect economic activity significantly less when policy uncertainty is high.

${ }^{7}$ Baker et al. (2016) collect a list of related papers and refer to them on the following website: http:// www.policyuncertainty.com/research.html

${ }^{8}$ Overall, Guay and Kothari (2003) suggest rethinking past empirical research on firms' derivatives use.

${ }^{9}$ Pástor and Veronesi $(2012,2013)$ note that uncertainty cannot be fully mitigated by diversification.

${ }^{10}$ Procedures to develop the index can be found here: http://www.policyuncertainty.com/media/ Coding_Guide.pdf.

${ }^{11}$ Like Baker et al. (2016), we also conducted an audit by asking our research assistant to do a manual search of the mentioned newspaper in 2005, for the selected terms. The audit provided a similar result to the EPU we use here.

${ }^{12} \mathrm{We}$ exclude financial firms, as these firms are financial intermediaries; they are derivative traders rather than end-users. More specifically, they enter into derivative contracts for trading purposes on their own account, or on behalf of their customers.

${ }^{13} \mathrm{We}$ focus on domestic MNE firms among 881 firms in our sample.

${ }^{14}$ We also conduct an analysis with other types of derivatives, such as interest rate and commodity price derivatives. Also, we conduct a two-way clustering by country and industry - of the baseline model. The findings are consistent with what this study reports; they are available from the authors upon request.

${ }^{15}$ To proceed with this procedure, we use the module CLUSTSE in Stata.

${ }^{16}$ This index measures the quality of public and civil services, and the credibility of a government's 
commitment to policies. We position all of these variables on a scale from -2.5 (weak governance) to 2.5 (strong governance), which we obtained from the World Bank.

${ }^{17}$ As an alternative, building upon Alesina and Perotti (1996) to capture political instability within the country, we can use the Political Risk variable from the World Bank. The main findings are consistent with what we report in this article.

${ }^{18}$ Regarding global policy uncertainty, and given the highly international involvement of firms in our sample, we expect that fluctuation in the global market would induce firms to use derivatives more intensively in response to such fluctuation. An interesting question is whether firm hedging behavior is more sensitive to global policy uncertainty, or a country's specific policy uncertainty. To capture the effect of global economic uncertainty, we use the S\&P 500 volatility index (VIX) to proxy for global policy uncertainty, which follows numerous studies (see Baker et al., 2016). We include VIX in Tables 4 and 5, Model 3.

${ }^{19}$ The estimated coefficient of VIX is insignificant, yet policy uncertainty still shows a significant effect on the intensity of derivatives use. This finding again points to the significant effect of policy uncertainty on a firm's hedging behavior, which is not captured by the effect of global uncertainty. Finally, it is worth noting that the interaction between institution quality and EPU is still negative and significant in all model specifications.

${ }^{20}$ The Baker et al. (2016) Categorical Data include a range of sub-indexes based solely on news data. These are derived using results from the Access World News database of over 2000 US newspapers. Each sub-index requires our economic, uncertainty, and policy terms, as well as a set of categorical policy terms. For instance, articles that fulfill our requirements for coding as EPU - and also contain the term 'federal reserve' - would be included in the monetary policy uncertainty sub-index. The list of categories can be found here: http://www.policyuncertainty.com/ categorical_terms.html.

${ }^{21}$ Market model is developed by Adler and Dumas (1984) and augmented by Jorion (1990).

${ }^{22}$ Daily and weekly data are noisier and usually afflicted by non-synchroneity problems (Allayannis \& Ofek, 2001).

\section{REFERENCES}

Aastveit, K. A., Natvik, G.J., \& Sola, S. 2013. Economic uncertainty and the effectiveness of monetary policy.
${ }^{23}$ In the multivariate tests, we use absolute rather than actual estimated exposure because the sign of exposure just measures the direction of risk exposure, while the magnitude of exposure is more important (Faff \& Marshall, 2005).

${ }^{24}$ It is likely that endogeneity exists in this model's specification. Better performing firms may have more incentive to use derivatives. As such, we also check the following model's specifications: a) include previous year performance (lagged $Y$ ) and see whether the main findings hold; $b$ ) lag the main predictors - level of EPU and derivatives use - by one period; and c) run a reverse regression to see whether increasing firm performance has an effect on the intensity of derivatives use. We find that the key findings are sustained. However, there is also some evidence of endogeneity, i.e., firms with better performance are more likely to use derivatives more intensively.

${ }^{25} \mathrm{We}$ also consider other measures of firm performance - commonly used in the literature - such as sale level per employee. We arrive at much the same results; please refer to Appendix B for further details.

${ }^{26}$ FT 500 2013, http://www.ft.com/indepth/ft500, Financial Times.

${ }^{27}$ Business Times, http://www.businesstimes.com. sg/companies-markets/ranking-of-singapore-companies -by-market-capitalisation-0.

${ }^{28}$ It is worth noting that there are a relatively great number of missing observations in our data analysis. The main reason is that we randomly selected firms, and the missing variables differ from firm to firm. For example, some firms have information about derivatives, yet do not have information about leverage. Other firms have missing variables on derivatives; however, they have information about leverage.

${ }^{29}$ Lewellen and Badrinath (1997) explain that asset vintages are assets in place for a firm on the date when a replacement cost measure is desired.

${ }^{30}$ LIFO stands for "Last in, First out," an inventory accounting. In this method of accounting, the last items placed into the firm's inventory are supposed to be the first ones sold (see Perfect \&Wiles, 1994).

Adler, M., \& Dumas, B. 1984. Exposure to currency risk: Definition and measurement. Financial Management, 13(2): 41-50. 
Alesina, A., \& Perotti, R. 1996. Income distribution, political instability, and investment. European Economic Review, 40(6): 1203-1228.

Alexopoulos, M., \& Cohen, J. 2015. The power of print: Uncertainty shocks, markets, and the economy. International Review of Economics \& Finance, 40: 8-28.

Allayannis, G., Brown, G. W., \& Klapper, L. F. 2003. Capital structure and financial risk: Evidence from foreign debt use in East Asia. Journal of Finance, 58(6): 2667-2709.

Allayannis, G., \& Ofek, E. 2001. Exchange rate exposure, hedging, and the use of foreign currency derivatives. Journal of International Money and Finance, 20: 273-296.

Allayannis, G., \& Weston, J. P. 2001. The use of foreign currency derivatives and firm market value. Review of Financial Studies, 14(1): 243-276.

Allen, L., \& Pantzalis, C. 1996. Valuation of the operating flexibility of multinational corporations. Journal of International Business Studies, 27(4): 633-653.

Anderson, A., \& Gupta, P.P. 2009. A cross-country comparison of corporate governance and firm performance: Do financial structure and the legal system matter? Journal of Contemporary Accounting \& Economics, 5(2): 61-79.

Aretz, K., \& Bartram, S. M. 2010. Corporate hedging and shareholder value. Journal of Financial Research, 33: 317-371.

Asiri, B. K. 2014. An empirical analysis of country risk ratings. Journal of Business Studies Quarterly, 5(4): 52-68.

Azad, A. S. M. S., Fang, V., \& Hung, C. H. 2012. Linking the interest rate swap markets to the macroeconomic risk: The UK and US evidence. International Review of Financial Analysis, 22: 38-47.

Baker, S. R., Bloom, N., \& Davis, S. J. 2016. Measuring economic policy uncertainty. Quarterly Journal of Economics, 131(4):1593-1636.

Bartov, E., \& Bodnar, G.M. 1994. Firm valuation, earnings expectations, and the exchange-rate exposure effect. The journal of Finance, 49(5): 1755-1785.

Bartram, M. S., Brown, W. G., \& Conrad, J. (2011). The effects of derivatives on firm risk and value. Journal of Financial and Quantitative Analysis, 46(4): 967-999.

Bartram, S.M., Brown, G.W., and Fehle, F.R. 2009. International evidence on financial derivatives usage. Financial Management, Spring, pp. 185-206.

Beazer, Q.H., and Blake, D.J. 2011. September. It's all relative: Home country risk and FDI flows. In Politics of FDI Conference, Niehaus Center for Globalization and Governance, Princeton University, September (pp. 23-24).

Beber, A., \& Brandt, M. W. 2009. When it cannot get better or worse: The asymmetric impact of good and bad news on bond returns in expansions and recessions. Review of Finance, 14(1): 119-155.

Beber, A., Brandt, M. W., \& Kavajecz, K. A. 2009. Flight-toquality or flight-to-liquidity? Evidence from the euro-area bond market. Review of Financial Studies, 22(3): 925-957.

Bell, R. G., Filatotchev, I., \& Rasheed, A. A. 2012. The liability of foreignness in capital markets: Sources and remedies. Journal of International Business Studies, 43(2): 107-122.

Bernanke, B. S. 1983. Irreversibility, uncertainty, and cyclical investment. The Quarterly Journal of Economics, 98(1): 85-106.

Berghöfer, B., \& Lucey, B. 2014. Fuel hedging, operational hedging and risk exposure-Evidence from the global airline industry. International Review of Financial Analysis, 34: 124-139.

Berk, R. A. 1983. An introduction to sample selection bias in sociological data. American Sociological Review, 48(3): 386-398.

Bhaumik, S. K., Driffied, N., \& Zhou, Y. 2016. Country-specific advantage, firm-specific advantage and multinationality sources of competitive advantage in emerging markets: Evidence from electronics industry in China. International Business Review, 25: 165-176.

Biais, B., Foucault, T., \& Moinas, S. 2015. Equilibrium fast trading. Journal of Financial Economics, 116(2): 292-313.

Blass, A., \& Yafeh, Y. 2001. Vagabond shoes longing to stray: Why foreign firms list in the United States. Journal of Banking Finance, 25(3): 555-572.
Bloom, N. 2009. The impact of uncertainty shocks. Econometrica, 77(3): 623-685.

Bloom, N., Bond, S., \& Van Reenen, J. 2007. Uncertainty and investment dynamics. The Review of Economic Studies, 74(2): 391-415.

Bodnar, G. M., \& Wong, M. F. 2003. Estimating exchange rate exposures: issues in model structure. Financial Management, 32(1): 35-67.

Bolton, P., \& Oehmke, M. 2015. Should derivatives be privileged in bankruptcy? The Journal of Finance, 70(6): 2353-2394.

Boudoukh, J., Feldman, R., Kogan, S., \& Richardson, M. 2013. Which news moves stock prices? a textual analysis (No. w18725). National Bureau of Economic Research.

Brainard, W.C., \& Tobin, J. 1968. Pitfalls in financial model building. The American Economic Review, 58(2): 99-122.

Brogaard, J., \& Detzel, A. 2015. The asset-pricing implications of government economic policy uncertainty. Management Science, 61(1): 3-18.

Brown, G. W., Crabb, P. R., \& Haushalter, D. 2006. Are firms successful at selective hedging? The Journal of Business, 79(6): 2925-2949.

Buckley, P. J., \& Casson, M. 1976. The Future of Multinational Enterprise. London: Macmillan.

Cameron, A. C., Gelbach, J. B., \& Miller, D. L. 2008. Bootstrapbased improvements for inference with clustered errors. The Review of Economics and Statistics, 90(3): 414-427.

Campello, M., Lin, C., Ma, Y., \& Zou, H. 2011. The real and financial implication of corporate hedging. Journal of Finance, 66(5): 1615-1647.

Castellani, D., \& Zanfei, A. 2006. Multinational Firms, Innovation and Productivity. Cheltenham: Edward Elgar Publishing.

Cetorelli, N., \& Peristiani, S. 2015. Firm value and cross listings: The impact of stock market prestige. Journal of Risk and Financial Management, 8(1): 150-180.

Chang, F. Y., Hsin, C. W., \& Shiah-Hou, S. R. 2013. A reexamination of exposure to exchange rate risk: The impact of earnings management and currency derivative usage. Journal of Banking \& Finance, 37(8): 3243-3257.

Charumathi, B., \& Kota, H. B. 2012. On the determinants of derivative usage by large Indian non-financial firms. Global Business Review, 13(2): 251-267.

Chen, J., \& King, T. H. D. 2014. Corporate hedging and the cost of debt. Journal of Corporate Finance, 29: 221-245.

Choi, J. J., \& Jiang, C. 2009. Does multinationality matter? Implications of operational hedging for the exchange risk exposure? Journal of Banking \& Finance, 33: 1973-1982.

Chung, C. H., Lee, S. H., Beamish, P., \& Isobe, T. 2010. Subsidiary expansion/contraction during times of economic crisis. Journal of International Business Studies, 41(3): 500-525.

Čihák, M., Demirgüç-Kunt, A., Feyen, E., and Levine, R. 2012. Benchmarking Financial Systems Around the World. World Bank Policy Research Working Paper 6175, World Bank, Washington, DC.

Colombo, V. 2013. Economic policy uncertainty in the US: Does it matter for the Euro Area? Economics Letters, 121(1): 39-42.

Davis, S.J. 2016. An Index of Global Economic Policy Uncertainty (No. w22740). National Bureau of Economic Research.

Duanmu, J. L. 2014. State-owned MNCs and host country expropriation risk: The role of home state soft power and economic gunboat diplomacy. Journal of International Business Studies, 45(8): 1044-1060.

Dunning, J. H. 1977. Trade, location of economic activity and the MNE: A search for an eclectic approach. In The international allocation of economic activity (pp. 395-418). Palgrave Macmillan.

Dunning, J. H., \& Lundan, S. M. 2008. Institutions and the OLI paradigm of the multinational enterprise. Asia Pacific Journal of Management, 25: 573-593.

Dunning, J. H., \& Rugman, A. M. 1985. The influence of Hymer's dissertation on theories of foreign direct investment. American Economic Review, 75: 228-232. 
Durnev, A. 2010. December. The real effects of political uncertainty: Elections and investment sensitivity to stock prices. In Paris December 2010 Finance Meeting EUROFIDAI-AFFI.

Faff, R.W., \& Marshall, A. 2005. International evidence on the determinants of foreign exchange rate exposure of multinational corporations. Journal of International Business Studies, 36(5): 539-558.

Fatemi, A. M. 1984. Shareholder benefits from corporate international diversification. The Journal of Finance, 39: 1325-1344.

Froot, K.A., Scharfstein, D.S., \& Stein, J.C. 1993. Risk management: Coordinating corporate investment and financing policies. The Journal of Finance, 48(5): 1629-1658.

Gastineau, G., Smith, D., \& Todd, R. 2001. Risk Management, Derivatives, and Financial Analysis under SFAS No. 133, Research Foundation of AIMR.

Gay, G. D., Lin, C. M., \& Smith, S. D. 2011. Corporate derivatives use and the cost of equity. Journal of Banking \& Finance, 35: 1491-1506.

Gentzkow, M., \& Shapiro, J.M. 2010. What drives media slant? Evidence from US daily newspapers. Econometrica, 78(1): 35-71.

Grosse, R., \& Trevino, L. 1996. Foreign direct investment in the United States: An analysis by country of origin. Journal of International Business Studies, 27(1): 139-155.

Guay, W., \& Kothari, S.P. 2003. How much do firms hedge with derivatives? Journal of Financial Economics, 70(3): 423-461.

Gulen, H., \& Ion, M. 2015. Policy uncertainty and corporate investment. Review of Financial Studies, 29(3):523-564.

Gunnemann, J. 2014. The impact of policy-related uncertainty on the economy: New evidence from Europe.

Handley, K., \& Limao, N. 2012. Trade and Investment Under Political Uncertainty: Theory and Firm Evidence. working paper, National Bureau of Economic Research. http://www. nber.org/papers/w17790.

Hoberg, G., \& Phillips, G. 2010. Product market synergies and competition in mergers and acquisitions: A text-based analysis. The Review of Financial Studies, 23(10): 3773-3811.

Huang, T., Wu, F., Yu, J., \& Zhang, B. 2015. Political risk and dividend policy: Evidence from international political crises. Journal of International Business Studies, 46: 574-595.

Hughes, J. S., Logue, D. E., \& Sweeney, R. J. 1975. Corporate international diversification and market assigned measure of risk and diversification. Journal of Financial and Quantitative Analysis, 10: 627-637.

Hull, J. 2012. Risk management and financial institutions, + Web Site (Vol. 733). Wiley.

Hutson, E., \& Stevenson, S. 2010. Openness, hedging incentives and foreign exchange exposure: A firm-level multi-country study. Journal of International Business Studies, 41(1): 105-122.

Jorion, P. 1990. The exchange-rate exposure of US multinationals. Journal of business, 63(3): 331-345.

Judge, A. 2006. Why and how UK firms hedge. European Financial Management, 12(3): 407-441.

Julio, B., \& Yook, Y. 2012. Political uncertainty and corporate investment cycles. The Journal of Finance, 67(1): 45-83.

Kho, B. C., \& Stulz, R.M. 2000. Banks, the IMF, and the Asian crisis. Pacific-Basin Finance lournal, 8(2): 177-216.

Kim, H.T., Papanastassiou, M., \& Nguyen, Q. 2016. Linking Country Governance Quality and Derivatives Use: Insights From Firms' Hedging Behavior In East Asia. Working Paper.

Kim, H.T., Papanastassiou, M., \& Nguyen, Q. 2017. Multinationals and the impact of corruption on financial derivatives use and firm value: Evidence from East Asia. Journal of Multinational Financial Management, 39: 39-59.

Knight, F. 1921. Risk, uncertainty, and profit. Hart Schaffner and Marx prize essays no 31. Boston and New York: Houghton Mifflin.

Kumar, P., \& Rabinovitch, R. 2013. CEO entrenchment and corporate hedging: Evidence from the oil and gas industry. Journal of Financial and Quantitative Analysis, 48(3): 887-917.

Lang, L. H. P., \& Stulz, R. M. 1984. Tobin's Q, corporate diversification, and firm performance. Journal of Political Economy, 102(6): 1248-1280.
Lee, S. H., \& Song, S. 2012. Host country uncertainty, intraMNC production shifts, and subsidiary performance. Strategic Management Journal, 33: 1331-1340.

Lewellen, W. G., \& Badrinath, S. G. 1997. On the measurement of Tobin's Q. Journal of Financial Economics, 44: 77-122.

Lievenbrück, M., \& Schmid, T. 2014. Why do firms (not) hedge?-Novel evidence on cultural influence. Journal of Corporate Finance, 25: 92-106.

Lindenberg, E. B., \& Ross, S. A. 1981. Tobin's q ratio and industrial organization. Journal of business, 54(1): 1-32.

Michel, A., \& Shaked, I. 1986. Multinational corporations vs. domestic corporations: Financial performance and characteristics. Journal of international business studies, 17(3): 89-100.

Modigliani, F., \& Miller, M. H. 1958. The cost of capital, corporation finance and the theory of investment. The American Economic Review, 48: 261-297.

Muller, A., \& Verschoor, W. F. 2007. Asian foreign exchange risk exposure. Journal of the Japanese and International Economies, 21(1): 16-37.

Nance, D. R., Smith, C. W., \& Smithson, C.W. 1993. On the determinants of corporate hedging. The journal of Finance, 48(1): 267-284.

Pan, M. S., Fok, R. C. W., \& Liu, Y. A. 2007. Dynamic linkages between exchange rates and stock prices: Evidence from East Asian markets. International Review of Economics \& Finance, 16(4): 503-520.

Pantzalis, C., Simkins, B. J., \& Laux, P. A. 2001. Operational hedges and the foreign exchange exposure of US multinational corporations. Journal of International Business Studies, 32(4): 793-812.

Park, S. H., Suh, J., \& Yeung, B. 2013. Do multinational and domestic corporations differ in their leverage policies? Journal of Corporate Finance, 20: 115-139.

Parsley, D. C., \& Popper, H. A. 2006. Exchange rate pegs and foreign exchange exposure in East and Southeast Asia. Journal of International Money and Finance, 25(6): 992-1009.

Pástor, L., \& Veronesi, P. 2012. Uncertainty about government policy and stock prices. Journal of Finance, 67(4): 1219-1264.

Pástor, L., \& Veronesi, P. 2013. Political uncertainty and risk premia. Journal of Financial Economics, 110: 520-545.

Perfect, S. B., \& Wiles, K. W. 1994. Alternative constructions of Tobin's Q: An empirical comparison. Journal of Empirical Finance, 1: 313-341.

Petersen, M. A. 2009. Estimating standard errors in finance panel data sets: Comparing approaches. The Review of Financial Studies, 22(1): 435-480.

Scott-Kennel, J., \& Giroud, A. 2015. MNEs and FSAs - network knowledge, strategic orientation and performance. Journal of World Business, 50: 94-107.

Smith, C. W., and Stulz, R.M. 1985. The determinants of firms' hedging policies. Journal of financial and quantitative analysis, 20(4): 391-405.

Supanvanij, J., \& Strauss, J. 2010. Corporate derivative use and the composition of CEO compensation. Global Finance Journal, 21: $170-185$.

Syriopoulos, T., Makram, B., \& Boubaker, A. 2015. Stock market volatility spillovers and portfolio hedging - BRICS and the financial crisis. International Review of Financial Analysis, 39: 7-18.

Tallman, S. 1988. Home country political risk and foreign direct investment in the United States. Journal of International Business Studies, 19(2): 219-233.

Tobin, J. 1969. A general equilibrium approach to monetary theory. Journal of money, credit and banking, 1(1): 15-29.

Tufano, P. 2003. Financial innovation. Handbook of the Economics of Finance, 1: 307-335.

Wooldridge, J. M. 2003. Cluster-sample methods in applied econometrics. The American Economic Review, 93(2): 133-138.

Zaheer, S. 2002. The liability of foreignness, redux: A commentary. Journal of International Management, 8(3): 351-358.

Zhou, V.Y., \& Wang, P. 2013. Managing foreign exchange risk with derivatives in UK non-financial firms. International Review of Financial Analysis, 29: 294-302. 


\section{APPENDIX A}

Linking EPU, Derivatives Use, and Firm Performance: Using Alternative Measures of Firm Performance See Table 11.

Table 11 Determinants of firm performance (measured by log of sales level per employee)

\begin{tabular}{|c|c|c|c|c|}
\hline & Model 1 & Model 2 & Model 3 & Model 4 \\
\hline \multirow[t]{2}{*}{ Firm size (Log) } & $0.268^{* *}$ & $0.255^{*}$ & $0.422^{* * *}$ & $0.477^{\star \star \star}$ \\
\hline & $(0.025)$ & $(0.032)$ & $(0.001)$ & $(0.001)$ \\
\hline \multirow[t]{2}{*}{ Derivative intensity } & $0.277 \dagger$ & & $0.266 \dagger$ & 0.164 \\
\hline & $(0.08)$ & & $(0.122)$ & $(0.142)$ \\
\hline \multirow[t]{2}{*}{ EPU } & & $-0.577^{*}$ & $-0.528^{*}$ & $-0.622^{\star * *}$ \\
\hline & & $(0.026)$ & $(0.046)$ & $(0.008)$ \\
\hline \multirow[t]{2}{*}{$\mathrm{EPU} \times$ Derivative intensity } & & & & $0.226^{\star \star *}$ \\
\hline & & & & $(0.001)$ \\
\hline \multirow[t]{2}{*}{ Cross-listed } & 0.001 & 0.006 & 0.002 & 0.008 \\
\hline & $(0.157)$ & $(0.112)$ & $(0.228)$ & $(0.116)$ \\
\hline Control for firm specifics & Yes & Yes & Yes & Yes \\
\hline Control for other macro variables & Yes & Yes & Yes & Yes \\
\hline Adjusted $\mathrm{R}^{2}$ & 0.40 & 0.42 & 0.47 & 0.48 \\
\hline No. of firms & 881 & 881 & 881 & 881 \\
\hline No. of observations & 3123 & 3123 & 3123 & 3123 \\
\hline
\end{tabular}

Note: The dependent variable is the firm's sales level per worker in natural logarithm. The coefficients and significance levels are reported for each model. We used year and industry fixed effects in all models. $p$ values are in parentheses.

+ if $\mathrm{p}<0.10,{ }^{*}$ if $\mathrm{p}<0.05 ;{ }^{* *}$ if $\mathrm{p}<0.01 ;{ }^{* *}$ if $\mathrm{p}<0.001$.

See Table 12.

APPENDIX B

Table 12 Fixed Effects Model

\begin{tabular}{|c|c|c|c|}
\hline Variables & Domestic firms & Domestic MNCs & Foreign affiliates \\
\hline \multicolumn{4}{|l|}{ Panel A: Country risks } \\
\hline DER & $\begin{array}{l}-0.1248^{* *} \\
(0.028)\end{array}$ & $\begin{array}{l}-0.1476^{\star * *} \\
(0.001)\end{array}$ & $\begin{array}{l}0.0259 \\
(0.585)\end{array}$ \\
\hline Firm size & $\begin{array}{l}-0.1391 \\
(0.470)\end{array}$ & $\begin{array}{l}-0.302^{\star} \\
(0.073)\end{array}$ & $\begin{array}{l}-0.645 \\
(0.102)\end{array}$ \\
\hline Leverage & $\begin{array}{l}-0.0346 \\
(0.401)\end{array}$ & $\begin{array}{l}0.0449 \\
(0.563)\end{array}$ & $\begin{array}{l}-0.0343^{* *} \\
(0.024)\end{array}$ \\
\hline FORSALES & $\begin{array}{l}0.068^{*} \\
(0.065)\end{array}$ & $\begin{array}{l}0.0108 \\
(0.536)\end{array}$ & $\begin{array}{l}0.0707^{* *} \\
(0.049)\end{array}$ \\
\hline GEOMART & $\begin{array}{l}0.3688 \\
(0.468)\end{array}$ & $\begin{array}{l}0.2841 \\
(0.111)\end{array}$ & $\begin{array}{l}-0.2539 \\
(0.334)\end{array}$ \\
\hline Cross-listed & $\begin{array}{l}-0.2883 \\
(0.361)\end{array}$ & $\begin{array}{l}0.2369 * \\
(0.088)\end{array}$ & $\begin{array}{l}-0.0984 \\
(0.965)\end{array}$ \\
\hline GDP per capita & $\begin{array}{l}0.568^{* *} \\
(0.046)\end{array}$ & $\begin{array}{l}-0.1033 \\
(0.457)\end{array}$ & $\begin{array}{l}-0.0302 \\
(0.976)\end{array}$ \\
\hline DEPOSITSTOGDP & $\begin{array}{l}-0.819 \\
(0.340)\end{array}$ & $\begin{array}{l}-0.120^{* *} \\
(0.038)\end{array}$ & $\begin{array}{l}-0.0689^{* *} \\
(0.039)\end{array}$ \\
\hline
\end{tabular}


Table 12 (Continued)

\begin{tabular}{|c|c|c|c|}
\hline Variables & Domestic firms & Domestic MNCs & Foreign affiliates \\
\hline \multirow[t]{2}{*}{ Rule of law } & 0.4911 & 0.1339 & $-0.6676^{\star *}$ \\
\hline & $(0.912)$ & $(0.536)$ & $(0.021)$ \\
\hline \multirow[t]{2}{*}{ Intercept } & 20.21 & 189.8 & 3.372 \\
\hline & $(0.859)$ & $(0.349)$ & $(0.786)$ \\
\hline Country dummies & Yes & Yes & Yes \\
\hline Industry dummies & Yes & Yes & Yes \\
\hline Year dummies & Yes & Yes & Yes \\
\hline No. of observations & 2007 & 2506 & 438 \\
\hline \multicolumn{4}{|l|}{ Panel B: FX exposure } \\
\hline \multirow[t]{2}{*}{ FCD } & $-0.1010^{* * *}$ & $-0.1311^{*}$ & -0.138 \\
\hline & $(0.007)$ & $(0.088)$ & $(0.957)$ \\
\hline \multirow[t]{2}{*}{ Firm size } & $-0.2095^{\star * *}$ & $-0.0178^{*}$ & $-0.1636^{*}$ \\
\hline & $(0.003)$ & $(0.066)$ & $(0.057)$ \\
\hline \multirow[t]{2}{*}{ Leverage } & -0.0778 & $-0.0395^{*}$ & 0.0515 \\
\hline & $(0.604)$ & $(0.056)$ & $(0.868)$ \\
\hline \multirow[t]{2}{*}{ FORSALES } & 0.0258 & 0.0391 & 0.0340 \\
\hline & $(0.335)$ & $(0.476)$ & $(0.949)$ \\
\hline \multirow[t]{2}{*}{ GEOMART } & -0.767 & -0.0323 & 0.1491 \\
\hline & $(0.631)$ & $(0.435)$ & $(0.516)$ \\
\hline \multirow[t]{2}{*}{ Cross-listed } & 0.1579 & -0.0395 & -0.1297 \\
\hline & $(0.469)$ & $(0.177)$ & $(0.973)$ \\
\hline \multirow[t]{2}{*}{ GDP per capita } & -0.3777 & $0.185^{\star *}$ & $0.651^{\star *}$ \\
\hline & $(0.105)$ & $(0.049)$ & $(0.025)$ \\
\hline \multirow[t]{2}{*}{ DEPOSITSTOGDP } & $-0.103^{* * *}$ & $-0.0472^{\star *}$ & -0.1971 \\
\hline & $(0.006)$ & $(0.020)$ & $(0.409)$ \\
\hline \multirow[t]{2}{*}{ Rule of law } & -0.4592 & 0.159 & -0.4365 \\
\hline & $(0.291)$ & $(0.430)$ & $(0.878)$ \\
\hline \multirow[t]{2}{*}{ Intercept } & 51.52 & $-2.404^{\star}$ & 149.4 \\
\hline & $(0.135)$ & $(0.067)$ & $(0.396)$ \\
\hline Country dummies & Yes & Yes & Yes \\
\hline Industry dummies & Yes & Yes & Yes \\
\hline Year dummies & Yes & Yes & Yes \\
\hline No. of observations & 1053 & 1250 & 410 \\
\hline \multicolumn{4}{|l|}{ Panel C: IR exposure } \\
\hline \multirow[t]{2}{*}{ IRD } & $-0.1630^{* *}$ & $-0.1750^{\star *}$ & $-0.0307^{*}$ \\
\hline & $(0.018)$ & $(0.046)$ & $(0.092)$ \\
\hline \multirow[t]{2}{*}{ Firm size } & -0.565 & $-0.0737^{* *}$ & -0.0659 \\
\hline & $(0.878)$ & $(0.041)$ & $(0.470)$ \\
\hline \multirow[t]{2}{*}{ Leverage } & -0.0960 & $-0.0235^{* *}$ & $-0.0217^{*}$ \\
\hline & $(0.911)$ & $(0.012)$ & $(0.100)$ \\
\hline \multirow[t]{2}{*}{ FORSALES } & $0.397^{\star *}$ & 0.0110 & 0.0747 \\
\hline & $(0.037)$ & $(0.594)$ & $(0.924)$ \\
\hline \multirow[t]{2}{*}{ GEOMART } & -0.186 & -0.107 & 0.2165 \\
\hline & $(0.989)$ & $(0.433)$ & $(0.454)$ \\
\hline Cross-listed & 0.1757 & -0.107 & -0.3521 \\
\hline & $(0.860)$ & $(0.253)$ & $(0.493)$ \\
\hline GDP per capita & $-0.1909^{* * *}$ & -0.876 & $-0.2480^{* *}$ \\
\hline & $(0.000)$ & $(0.516)$ & $(0.041)$ \\
\hline DEPOSITSTOGDP & $-0.4486^{\star * \star}$ & $-0.0432^{\star * *}$ & $-0.0563^{* *}$ \\
\hline & $(0.000)$ & $(0.000)$ & $(0.044)$ \\
\hline Rule of law & $-0.2236^{\star * \star}$ & 0.420 & -0.3139 \\
\hline & $(0.002)$ & $(0.320)$ & $(0.115)$ \\
\hline Intercept & $1522.9^{* * *}$ & 8.560 & 6.953 \\
\hline & $(0.000)$ & $(0.487)$ & $(0.836)$ \\
\hline Country dummies & Yes & Yes & Yes \\
\hline
\end{tabular}


Table 12 (Continued)

\begin{tabular}{clll}
\hline Variables & Domestic firms & Domestic MNCs & Foreign affiliates \\
\hline Industry dummies & Yes & Yes & Yes \\
Year dummies & Yes & Yes & Yes \\
No. of observations & 2061 & 2398 & 430 \\
\hline
\end{tabular}

Note: This table presents the impacts of derivatives use on exposure across domestic firms, domestic MNCs, and foreign affiliates from fixed effects models. The dependent variables are absolute values of exposure to EPU (panel A), exchange rate risks (panel B), and interest rate risks (panel C). DER is the notional value of any derivative contracts in thousands of USD, scaled by total assets. FCD is the notional value of foreign currency derivatives in thousands of USD, scaled by total assets. IRD is the notional value of interest rate derivatives in thousands of USD, scaled by total assets. $p$ values are in parentheses. Asterisks ${ }^{* *},{ }^{* *}$, and ${ }^{*}$ indicate significance at the 1,5 , and $10 \%$ level, respectively.

\section{APPENDIX C}

\section{Sample Selection}

Our sample includes 881 non-financial firms across 34 different industries in the period of 2003-2013. Following most prior studies, we selected the toplisted companies ranked by market capitalization on the stock exchanges of the eight countries in the sample. We obtained the list of Japanese firms from the Financial Times list of the Japan FT500; ${ }^{26}$ the list of Singapore companies from the Business Times; ${ }^{27}$ and for other companies, we obtain information on the ranking of listed companies from websites of stock exchanges of each country and from the list of Bloomberg. We excluded firms that did not have annual reports in English or did not have annual reports from 2003 to 2013 . Finally, we have a sample of 881 non-financial firms in total, including 149 Singapore firms, 151 Japanese firms, 103 Thai firms, 146 Hong Kong firms, 101 Chinese firms, 160 Malaysian firms, 39 Indonesian firms, and 32 Philippino firms.

There are two main reasons why we chose large firms. Firstly, large firms were more likely to be involved in international business activities and thereby have exposure to financial risks. Because many firms are expected to have exposure to financial risks, our sample potentially provides a rich crosssection of derivatives users and non-users. Secondly, there was a high likelihood that large firms were actively encouraged to report their derivatives usage in their annual reports during the sample period.

We chose the period of 2003-2013 for investigation because our data span the global financial crisis of 2007-2008, which generated real exogenous shocks to firms, thereby providing us a unique natural experiment of derivatives use and financial risks, and allows us to provide new insights into firms' hedging activities and economic policy uncertainty before, during, and after that turbulent period.
We also thought about sample selection bias given a great number of missing observations in our study. ${ }^{28}$ For instance, firms might report derivatives in years with high EPU. To investigate potential bias, we use a simple $t$ test to check variables such as the amount of derivatives, EPU, and other country-level controls. We do not find systematic difference between the missing observations and the available observations. Next, we implement a Heckman correction model (1976) where two equations are developed: one for selection and the other for the dependent variable. These two equations are estimated simultaneously. It is worth noting that a probit estimation of the selection model is used in the primary regression model to test if there is a significant selection bias. We use firm specifics, industry and year binaries, EPU, and other country variables to estimate the selection model to check if the observations that are not included in our main models are systematically different from those that are included in the main models. It is noted that the two-stage estimator method only outperforms an ordinary least squares (OLS) method if selection bias is severe (Berk, 1983). We find that neither is the sample selection bias significant nor do the regression coefficients substantially differ between the two-step estimator and the OLS models. As such, we use OLS regression models with robust standard errors in our estimations.

\section{APPENDIX D}

\section{Estimation of Tobin's Q}

Pantzalis, Simkins, \& Laux (2001) define foreign affiliate as an independent organizational unit, which is located in any sample country, wholly or partially managed and controlled by a foreign parent multinational corporation (MNC). As such, our sample foreign affiliates have their own 
independent balance sheets and financial statements with separate market prices. Thus, data of their market prices are available on Datastream database, and we obtained those data from Datastream. On that basis, we calculated Tobin's Q for every foreign affiliate.

Regarding our Tobin's Q calculation, we would like to introduce and describe it in details below.

Since its introduction to the literature of financial economics approximately a half of century ago, Tobin's Q has become an increasingly popular measure of firm performance. As defined by Brainard and Tobin (1968) and Tobin (1969), Tobin's Q is the ratio between the firm's market value and the replacement cost of its capital stock, this ratio has become known as Tobin's average $Q$ or Tobin's Q in short. As such, they argue that investment is stimulated when capital is valued more highly in the market than it costs to manufacture it, and deterred when its valuation is less than its replacement cost. Another way to indicate the same point is that firms which display Tobin's $\mathrm{Q}$ greater than unity are judged as using scare resources effectively, and those firms with Tobin's $Q$ less than unity are considered as using resources poorly. Because of that, Brainard \& Tobin (1968) and Tobin (1969) propose that this ratio be used to measure the firm's incentive to invest in capital.

To the best of our knowledge, Allayannis and Weston (2001) are the first to apply this methodology to examine the effect of derivatives use on firm value. Following Allayannis and Weston (2001), among others, we define Tobin's Q as the ratio of firm's market value to replacement costs of assets, evaluated at the end of the fiscal year for each firm. We then need to estimate Tobin's $Q$ for each firm in the sample. Lindenberg and Ross (1981) developed a methodology for measuring Tobin's $\mathrm{Q}$, which has become the roadmap for subsequent studies, in which it is expressed as follows:

\section{Market value of the firm \\ Tobin's $\mathrm{Q}=$ \\ Total replacement cost of assets \\ Market value (equity + debt + preferred stock) \\ Replacement cost (plant + equipment + inventories)}

Our methodology for constructing market value of the firm closely follows Perfect and Wiles (1994), Lewellen and Badrinath (1997), Allayannis and Weston (2001). According to Perfect and Wiles
(1994), market value of a firm in year $t$ is the sum of year-end market values of equity, debt, and preferred stock. The year-end market value of a firm's equity is estimated by year-end per share stock price multiplied by the number of outstanding shares. Market value of a firm's preferred stock is the total preferred dividends capitalized by preferred stock yield index.

Lewellen and Badrinath (1997) and Allayannis and Weston (2001) propose somewhat different estimation of the firm's market value. In their estimation, market value of a firm consists of shortterm debt, long-term debt, preferred stock, and common stock. They suppose that short-term debt has a market value equal to book value, while longterm debt is estimated using a recursive methodology that measures maturity structure of a firm's long-term debt and accounts for changes in the yield on A-rated industrial bonds. Additionally, the market value of common stock is estimated by yearend share price multiplied by the number of outstanding shares. Lewellen and Badrinath (1997) estimate preferred stock as annual dividend obligations divided by the prevailing yield on medium grade preferred, while Allayannis and Weston (2001) measure market value of preferred stock using the year-end redemption value, which is suggested by Lang and Stulz (1994).

By the same token, to calculate the replacement cost of assets, we follow the procedure outlined in studies by Perfect and Wiles (1994), Lewellen and Badrinath (1997), Allayannis and Weston (2001). Perfect and Wiles (1994) note that a firm's assets can be decomposed into three constituents: (a) plant and equipment, (b) inventories, and (c) others. The replacement costs of plant, equipment, and inventories are estimated using three methodologies that employ a firm's replacement cost estimates or time series estimates based on historical data or both. The first methodology uses replacement cost figures provided by the firm. The second method is derived from the model of Lindenberg and Ross (1981), and the third technique calculates the end-of-year book value of a firm's total assets.

In this study, we follow Lewellen and Badrinath (1997), Allayannis and Weston (2001) approach of constructing replacement cost of assets, which is both simpler and more accurate. In their procedure, the replacement cost of assets is estimated as the sum of replacement cost of fixed assets plus inventories. As such, they calculate the replacement cost of fixed assets by deducing the vintages ${ }^{29}$ and 
depreciation pattern of in-place gross fixed assets. In addition, the replacement cost of inventories is measured as the sum of book value of inventories plus LIFO ${ }^{30}$ reserves. Allayannis and Weston (2001) demonstrate that the advantage of this methodology for estimating replacement cost is that it does not hinge on any initial conditions or "recursive build-up" period, which can lead to a serious impact on both the magnitude and ranking of Tobin's Q across firms as indicated by Lewellen and Badrinath (1997).

\section{ABOUT THE AUTHORS}

Quang Nguyen joined Business School, Middlesex University in 2013. Prior to that he was a faculty member at the Division of Economics at Nanyang Technological University in Singapore, and University of Lyon 2 in France. Incorporating insights from economics and psychology - i.e., behavioral economics - he conducts field experiments to explore behaviors of consumers in the market, as well as employees and managers in the firms. He has published in top academic journals such as the American Economic Review.

Trang Kim is a Senior Lecturer of International Finance at Foreign Trade University, Vietnam, and has been awarded PhD degree at Middlesex University Business School, UK. She won first prize at "The scientific research contests for students 2004" of Vietnam and won first prize of "VIFOTEC prize 2004" of Vietnam. She has published her paper entitled "Multinationals and the impact of corruption on financial derivatives use and firm value: Evidence from East Asia" in the Journal of
Multinational Financial Management. Her research interests include financial performances and financial management of multinational corporations (MNCs), risk management, financial derivatives use, and institutional theory.

Marina Papanastassiou is Professor of International Business at Middlesex University Business School, London. Professor Papanastassiou received her Ph.D. from the University of Reading and previously held positions in Copenhagen Business School, Denmark and Athens University of Economics and Business, Greece. Her research focuses on MNE subsidiary roles and MNE innovation strategies. Professor Papanastassiou has published in a number of leading academic refereed journals and co-authored with Robert Pearce two books on "The strategic development of Multinationals; subsidiaries and innovation, London: Palgrave MacMillan" (2009) and on "Multinationals, Technology and National Competitiveness, London: Edward Elgar Press" (1999). Professor Papanastassiou is a Fellow of the European International Business Academy (EIBA).

Open Access This article is distributed under the terms of the Creative Commons Attribution 4.0 International License (http://creativecommons.org/ licenses/by/4.0/), which permits unrestricted use, distribution, and reproduction in any medium, provided you give appropriate credit to the original author(s) and the source, provide a link to the Creative Commons license, and indicate if changes were made.

The original version of this article was revised. Since this paper was first published, the publisher has been informed of an additional contributing author that should have been included. The authorship has now been corrected online, and the author's biographical sketch has been added. No other changes have been made to the text.

Accepted by David Reeb, Area Editor, 14 March 2017. This article has been with the authors for three revisions. 